Georgia State University

ScholarWorks @ Georgia State University

7-1-2011

\title{
Economic Analysis of Labor Markets and Labor Law: An Institutional/Industrial Relations Perspective
}

Bruce E. Kaufman

Georgia State University, bkaufman@gsu.edu

Follow this and additional works at: https://scholarworks.gsu.edu/uwrg_workingpapers

\section{Recommended Citation}

Kaufman, Bruce E., "Economic Analysis of Labor Markets and Labor Law: An Institutional/Industrial Relations Perspective" (2011). UWRG Working Papers. 34.

https://scholarworks.gsu.edu/uwrg_workingpapers/34

This Article is brought to you for free and open access by the Usery Workplace Research Group at ScholarWorks @ Georgia State University. It has been accepted for inclusion in UWRG Working Papers by an authorized administrator of ScholarWorks @ Georgia State University. For more information, please contact scholarworks@gsu.edu. 
Working Paper 2011-7-1

July 2011

\title{
Economic Analysis of Labor Markets and Labor Law: An Institutional/Industrial Relations Perspective
}

\author{
Bruce E. Kaufman
}

Georgia State University 
Economic Analysis of Labor Markets and Labor Law:

An Institutional/Industrial Relations Perspective

\author{
Professor Bruce E. Kaufman \\ Department of Economics, Georgia State University \\ Center for Work, Organization and Wellbeing, Griffith University \\ Work and Employment Research Unit, University of Hertsfordshire
}

June 22, 2011

bkaufman@gsu.edu

Forthcoming in Michael Wachter and Cynthia Estlund (eds.), Law and Economics of Labor and Employment Law, Elgar, 2012. 
Economic Analysis of Labor Markets and Labor Law:

An Institutional/Industrial Relations Perspective

\section{Introduction}

In the twentieth century two intellectual traditions were the most influential in the American field of labor economics. The first was the tradition of institutional economics (IE) and its close offshoot industrial relations (IR), the second was the tradition of neoclassical economics (NE). This cleavage is refracted into the modern field of labor law where on one side is an IEIR-oriented traditional approach to labor law (e.g., Deakin and Wilkinson 2005; Estlund 2006; Arthurs 2007) and, on the other, a largely NE-inspired law and economics (L\&E) approach (Schwab 1997; Posner 2007; Medema 2010).

The institutional economics/industrial relations (IEIR) approach had its original home base at the University of Wisconsin and was led by John Commons; after the 1930s it evolved and expanded to include a neo-institutional branch centered in industrial relations and headed by non-Wisconsin labor economists such as John Dunlop, Clark Kerr, Richard Lester, and Lloyd Reynolds (McNulty 1980; Segal 1986; Kaufman 1988, 2006). Johnson (1975) refers to this tradition as the "old labor economics" and notes that it was partially separated from the main body of economics by its cross-disciplinary approach to theory-building, critical stance toward the competitive core of neoclassical theory, and neutral-to-sympathetic attitude toward trade unions and labor law. Other intellectual traditions, such as socio-economics, economic sociology, and comparative institutional analysis from political science, also feed into modern day IEIR. 
The cross-disciplinary dimension of original IEIR included considerable attention to the role of law as a determinant of an economy's institutional infrastructure and economic performance, making it a central player in what Hovenkamp (1990; also Pearson 1997) identifies as the twentieth century's first law and economics movement (FL\&EM). The FL\&EM was closely linked to the legal realist tradition in law (Mercuro and Medema 1997; Fried 1998); within the FL\&EM the subfield of labor law occupied a central place, illustrated by Commons and Andrews' pioneering text Principles of Labor Legislation (1916). After WWII many writers in traditional labor law field, as well as some of the nation's best-known labor mediators, arbitrators and policy officials, came from the IEIR camp. Examples are Henry Aaron, Archibald Cox, John Dunlop, and Arthur Goldberg; outside the USA are people such as Otto Kahn-Freund and Rodger Blanpain.

The neoclassical economics tradition in American labor economics goes back to the early $20^{\text {th }}$ century with principal roots in the work of English neoclassical economists, such as Alfred Marshall, John Hicks, and Joan Robinson; after World War II, however, NE research in labor economics shifted to America and soon acquired a well-recognized home base at another midwestern university -- the University of Chicago (McNulty 1980; Boyer and Smith 2001; Kaufman 2010a). Illustratively, Chicago professor H. Gregg Lewis is widely considered the "father" of modern labor economics and one reviewer (Biddle 1996) labels his style of economics "uncompromising neoclassicism" (p. 184). The neoclassical approach to the study of labor economics was until the 1970s largely an application of Marshallian partial equilibrium price theory to labor markets and wage determination; since then, however, contributions by Gary Becker and several other Nobel prize winning economists at Chicago (and elsewhere) have greatly broadened its domain and explanatory power by applying the tools of rational choice and 
equilibrium to an ever-widening range of non-market and imperfect market topics (Becker 1976, 1993; Lazear 2000). The neoclassical approach in America was overshadowed by the IEIR paradigm through the 1950s and the events of the Great Depression and New Deal in the eyes of many economists appeared to considerably discredit and marginalize NE's competitive "demand/supply” theoretical core. In hindsight, however, this was only a temporary setback and from the 1970s onward the "new" labor economics (aka, modern labor economics) of the NE school grew in strength and influence until by century's end it had become so dominant across American universities that younger researchers could be forgiven for thinking no earlier IEIR approach had ever been mainstream (Pearson 1997; Boyer and Smith 2001; Cahuc and Zylberberg 2004).

The University of Chicago was also home to what Hovenkamp (1990) refers to as the second law and economics movement (SL\&EM). It was fathered by Chicagoans Ronald Coase and Richard Posner, is anchored (particularly the Posnerian version) in neoclassical price theory, and seeks at a positive level to analyze how law influences economic activity and at a normative level how law should be constructed in order to promote economic efficiency. For reasons explained shortly, Chicago L\&E is wary-to-skeptical of government interference with private contracting and market outcomes (Schwab 1997; Medema 2010). The exemplar work is Posner's The Economic Analysis of Law (2007). In the labor law field Posner's article "Some Economic Aspects of Labor Law” (1984) was an early contribution, complemented by influential articles on subjects such as critique of the New Deal labor legislation and defense of employment-at-will by fellow Chicagoan Richard Epstein (e.g., Epstein 1983, 1984). In the last twenty-thirty years the Chicago-based law and economics (L\&E) movement has grown rapidly and now has a presence in many economics departments and law schools; naturally, in this process it has 
evolved beyond its Chicago and NE price theory roots but with many continuing linkages thereto in terms of theoretical and policy orientation (Medema and Mercuro 1997).

This chapter compares and contrasts the theoretical foundations of the first and second L\&E movements, the former located in IEIR and the second in NE, and the respective implications these theories have for analysis and evaluation of labor law. The chapter then demonstrates why, from an IEIR perceptive, the NE model used in SL\&EM has serious logical flaws and leads to unduly negative conclusions about the potential of labor law to enhance social welfare.

Before proceeding, several points of context are usefully established. First, IEIR and NE are not monolithic constructs and, as indicated above, NE now covers a very heterogeneous territory and, indeed, has expanded via a Coasian-inspired new institutional economics (NIE) to include a comparative study of institutions (Williamson 1985; Furubotn and Richter 2005). Hence, I define and use the two terms in the following delimited sense: IEIR typifies the people and ideas associated with the FL\&EM and NE similarly typifies people and ideas associated with the SL\&EM. Also, IEIR and NE are not the endpoints in the spectrum of labor market theory for other intellectual traditions occupy these positions, such as Marxist/radical and post-Keynesian labor economics to the left of IEIR and Austrian (libertarian) economics to the right of NE. Also, as used in this chapter "Wisconsin" and "Chicago" are best regarded as metaphors or allegorical symbols for two broader constructs, IEIR and FL\&EM on one hand and NE and SL\&EM on the other, that now extend far beyond their original home bases. The qualifier "in the USA" is also important since the IEIR and NE traditions discussed here, along with their parallel labor law traditions, are in a number of respects distinctively American products (Jacoby 2005). Finally, 
the term "labor law" is used in the expansive sense of covering collective and individual dimensions, the latter sometimes separately distinguished as employment law.

The reader may also wish to consult an earlier review by this author of the first and second L\&E movements (Kaufman 2009) as this chapter builds and expands on it.

\section{The Fundamental Dividing Line: “Assume a Competitive Labor Market”}

Modern economics, as indicated above, theorizes an immense range of institutions and behaviors, many of which do not even involve a market per se. When it comes to evaluation of labor law, however, people in NE and SL\&EM typically start the analysis from the same foundational concept, a concept I paraphrase as “assume a competitive labor market.” This often takes the pure form of a perfectly competitive labor market, with attendant demand/supply (DS) diagram; other times frictions and imperfections are introduced, such as in the NIE, but with the common assumption that competitive selection pressures remain strong enough that employers and employees are led to adopt (mostly) efficient contract terms. In the words of Nobel laureate Robert Solow (1990: xvi), “in today's preferred style the labor market is usually modeled as just clearing or, more subtly, producing efficient contracts.” Thus, economists use the terms "competitive market" and "competitive theory" in both a narrow (zero friction) and broad (positive friction) sense. By conventional agreement, however, the core property that any such model must preserve in order to remain "competitive” is prices (including wage rates) are parametric (a "given") and therefore individual firms and workers are price-takers and have no ability to set an alternative price and still find willing buyers and sellers (Varian 2010: 603).

[Insert Figure 1 about here] 
Figure 1 illustrates the competitive DS labor market model; it is an application to the labor market of the generic competitive market model that is a ubiquitous feature of scholarly expositions of modern L\&E (e.g., Mercuro and Medema 1997; Posner 2007; Cooter and Ulen 2010). The labor demand curve D and supply curve S determine an equilibrium wage $\mathrm{W}$ and employment level L. This conclusion by itself is not of great significance for analysis of labor law; what matters are the implications for social welfare.

One desirable social welfare property, mentioned in the Solow quote, is that competitive markets yield market-clearing prices and quantities. This means that competition causes wage rates to rise or fall until equilibrium is established where demand and supply are evenly balanced and neither a shortage nor excess of labor prevails. The beneficial aspect of market clearing is most apparent at the aggregate level; that is, the implication is that a competitive market economy automatically and without government guidance (“as if by an invisible hand”) tends to correct demand/supply imbalances and yield an equilibrium where the number of jobs available matches the number of people wanting to work (a definition of full employment).

A second desirable property, also alluded to in the Solow quotation, is that a competitive market economy leads to an efficient use of resources. Full employment of labor is clearly one dimension of efficiency (unemployment is a waste of labor resources). Another dimension is that competition and competitive wage rates sort and assign the nation's heterogeneous labor resources to their most productive use (e.g., the people with a comparative advantage at plumbing end up being plumbers). Yet a third dimension is that competition prevents employers from exploiting (underpaying) workers and provides employers with strong incentives to treat workers fairly (e.g., ill-treatment leads to a high turnover rate, a reputation as a bad employer, and less loyal and committed employees). A final dimension of efficiency, known as Pareto 
optimality, is that the nation's resources are allocated and utilized with no slack or waste; that is, the production of goods and services (or “wealth”) is at the economy's maximum limit and one person therefore can get more goods and services only if another gets less.

The DS model and the conditions and implications that come from it are, of course, highly idealized; further, as described in more detail below economists in the NE/NIE tradition have persuasively argued that many seeming labor market problems (e.g., unemployment, gender wage differentials) are actually efficient or competitive-like responses to underlying productivity, cost, and taste differentials. Not all economists, however, accept either the standard competitive model or the extended NE/NIE efficient contract version as useful interpretations of labor markets; others use them only as rough and ready benchmarks to get the analysis started. Hence a wide spectrum of opinion exists among economists regarding two related questions. The first is how well the competitive model and its various extensions and generalizations serve as a useful device for understanding and explaining labor markets and employment relationships; the second is to what degree the outcomes of a competitive labor market, even if attained, are beneficial for human welfare and therefore a desired object of public policy.

Here is located, I believe, a central dividing line between FL\&EM and SL\&EM. As a general statement (documented in what follows), the position of people affiliated with the first L\&E movement answer a mostly "no" to both of these questions while those with the second L\&E answer a mostly “yes.” For this reason Rodrik (2007; also McCloskey 1997) calls those in the SL\&EM group “first best” economists (market generated outcomes are typically the best that are realistically attainable) and those in the FL\&EM group "second best” (market generated outcomes can be improved upon through government regulation/coordination). Given this position, first best economists believe it is appropriate to start off analysis of labor law with the 
proposition "assume a competitive labor market;" second best economists, however, believe that the "assume a competitive labor market" proposition is by itself likely to lead to significant error in evaluating the pros and cons of labor law and must, therefore, either be used with significant qualifications or replaced with a different model.

III. The Competitive Labor Market Model in the Second L\&E Movement

In this section I take a deeper look at the role and significance of the "assume a competitive labor market" theme in the second L\&E movement -- where "competitive" is defined broadly to include efficient contract generalizations.

The effective birth date of both IEIR and NE is the 1880s (Blaug 1985; Hovenkamp 1990; Jacoby 2005). The marginal revolution had begun in the 1870s in the work of Jevons, Menger and Walras and by the 1880s had mostly displaced the classical approach of Malthus, Ricardo, and Marx. Not unrelatedly, this decade also saw the emergence of the Methodenstreit (i.e., "battle over method") - a fierce debate between over the pros and cons of two rival approaches to the science of economics (Rima 2009). On one side were the proponents of classical/neoclassical economics, principally located in Britain, Austria and to some degree France; on the other were proponents of historical/social economics (HSE), located principally in Germany but with strong presence in heterodox circles in Britain and other countries (Koot 1987; Pearson 1997). The HSE proponents were the insurgents and they sought to substantially modify the orthodox economics developed by Ricardo, Mill and Walras; considerably to their left were various Marxists and radicals but they sought to replace orthodoxy and thus fall outside our purview. 
The battle was ostensibly over the merits of a deductive versus inductive approach to theory-building in economics; under the surface, however, were also political considerations about individualism vs. collectivism and the extent of government regulation and redistribution (Ekelund and Hebert 2007: Chs. 9, 10). The main body of English deductive economists, for example, placed tight limits on government regulation of labor (some opposed maximum hour limits for women and children) while most HSE economists supported Germany’s pioneering program of workmen's compensation, unemployment insurance, and old age pensions. The deductive approach was favored by the classical/neoclassical side, exemplified in the abstract and mathematical theories of Ricardo and Walras, respectively. This approach to theorizing relied on a few general propositions about human nature and markets - typically portrayed as self-evident and akin to laws of nature (e.g., the "economic man" model of rational and selfinterested behavior; the law of supply and demand) - and proceeded to derive a corpus of causeeffect propositions. The spirit is well captured by Walras (1954 [1900]) who declares,

"In fact, the whole world may be looked upon as a vast general market made up of diverse special markets. Our task then is to discover the laws to which these purchases and sales tend to conform automatically. To this end, we shall suppose that the market is perfectly competitive, just as in pure mechanics we suppose, to start with, that machines are perfectly frictionless" (p. 84).

This quote highlights several features of the early neoclassical approach that have remained prominent over the decades and still inform the core of neoclassical microeconomics as taught to today's students and used in neoclassical-oriented treatises on law and economics (Rizvi 2007); indeed, it is from these historical roots that the "assume a competitive labor market” proposition originates. These features include a conceptual model of the economy derived from physics and classical mechanics where economic relations are closely akin to natural laws (e.g., the "law of demand"); a core model of human beings based on rationality and 
self-interest; a core model of markets based on demand and supply and competitive equilibrium; a core set of tools including constrained maximization, equilibrium, and efficiency; and adherence to the ideas of Adam Smith and Jean Baptiste Say - enshrined in the Invisible Hand idea and Say’s Law -- that self-interest and competition cause a market economy to automatically gravitate through flexible price adjustments toward a full-employment equilibrium (Kates 1998). These ideas are then rounded-out with the Pareto welfare principle, described earlier.

These insights were formalized in the 1950s by Arrow and Debreu into the first welfare theorem (FWT) of neoclassical economics (Blaug 2007). The FWT is also often called the "invisible hand" theorem. It states that a perfectly competitive economy is able to generate a Pareto optimal (aka, efficient) allocation of resources, meaning that the flexible price system puts the economy on its production possibility frontier (full utilization of resources, including labor) such that all gains from trade are exhausted and no readjustment of production/distribution can make one person better off without harming the welfare of another. Another characterization of Pareto optimality is "best feasible outcome," given the initial distribution of wealth and existing set of rules, laws, and other constraints. The FWT is often regarded as the most important result of economic science, per this statement by Just, Hueth and Schmitz (2004):

"This conclusion [the first welfare theorem] is probably the single most powerful result in the theory of market economies and is widely used by economists who believe that markets are competitive and that governments should not intervene in economic activity. Milton Friedman and the 'Chicago School' are the best known defenders of this position. In addition, because of its efficiency properties, competitive equilibrium offers a useful standard for policy analysis” (pp. 27-28).

Not surprisingly, the FWT leads to distinctly conservative-to-libertarian conclusions regarding policy and institutional interventions in labor markets. Illustratively, Mas-Colell, Whinston and Green (1995) state, "Under perfectly competitive conditions....the only possible 
welfare justification for intervention in the economy is the fulfillment of distributional objectives” (p. 524). With regard to the last part of this statement (distribution), they go on to discuss that one implication of the second welfare theorem (SWT) is that any desired redistribution for equity and fairness reasons should be done "before the market" in the form of ex ante lump sum taxes and payments rather than through use of methods that in some way interfere with demand/supply (e.g., a minimum wage law, collective bargaining) or endeavor to alter market outcomes ex post. [The SWT states that attainment of efficiency in a competitive market system is independent of the distribution of income and other endowments, implying that a well-chosen change in endowments and rules before trading starts will lead to outcomes that create the desired income distribution while leaving the market free to achieve these outcomes efficiently via DS.] Thus, the FWT and SWT effectively establish the prima facie case that in a competitive market economy the appropriate role of government is limited to certain basic functions such as maintenance of law and order, enforcement of contracts, provision of public goods, and lump-sum income transfers; otherwise, markets and employers and employees are best left to operate on their own with laissez-faire the general but not necessarily universal rule. As the quote above indicates, this position is particularly associated with the Chicago School of economics and many of the Chicagoans who founded and participated in the development of modern law and economics (Overfeldt 2007; Freedman 2008; Medema 2010).

One rarely sees the FWT and SWT mentioned in the labor economics literature or even in most NE discussions of labor law and policy. A reason is that NE-style labor economics is essentially applied microeconomics and the FWT and SWT are therefore typically presumed or implicit. Illustrative is the recent book The Economics of Imperfect Labor Markets (Boeri and van Ours 2008). In Chapter 1 they follow the standard theoretical line of argument in NE and 
SL\&EM: they state that the theoretical model economists use as the benchmark for evaluating labor market institutions and laws is the competitive DS model. They then lay out this model and demonstrate (1) why competition maximizes allocative efficiency and (2) how laws and institutions (e.g., unions) interfere with DS and create welfare losses. Without invoking the FWT and SWT in name, they nonetheless reach a minimalist verdict on the appropriate role of labor law and institutions. In their words,

"Because all labor market institutions introduce a wedge between labor demand and supply, they reduce the size of labor markets [and gains from trade]. If the labor market is competitive, the total surplus to be shared between firms and workers will be reduced after the introduction of any labor market institution....it should be possible to make everybody happier (or at least as happy) without them” (p. 18).

These pro-market conclusions rest, of course, on the supposition that real world labor markets are indeed approximately competitive or, more generally, that the outcomes are efficient as if the market were competitive. Reder (1982) claims the early Chicago economists who founded the SL\&EM took precisely this view. He states that their position was, “.... in the absence of sufficient evidence to the contrary, one may treat observed prices and quantities as good approximations to their long-run competitive equilibrium values” (p. 12). The implication is that labor markets, while having a variety of short-run frictions and imperfections, nonetheless yield outcomes that in the longer run are approximately competitive. An implication is that most alleged employment problems, such as discrimination, exploitation, and bad treatment, are of a surface or transitory nature that will get ironed-out by competition without government intervention (Friedman and Friedman 1990).

In the last two-to-three decades many economists with the SL\&EM have moved to a more generalized version of this proposition, particularly due to the influence of Coase and the 
NIE. Coase (1937) and later writers such as Williamson (1985) point out that a significant share of economic exchange takes place inside firms where there is no competitive market and management (in the absence of a union) decides employment matters by fiat. What, then, is to prevent managers from taking advantage of workers?

NE/NIE admits that sometimes workers are taken advantage of but denies that in most cases this is a widespread problem (Dow 1997). The line of argument proceeds along two levels. The first invokes the Coase theorem, an idea inspired by Coase (1960) but named and formally articulated by Stigler (1966). The theorem asserts that in a situation of zero transaction cost (frictionless/zero-cost trading) individual economic agents have an incentive to exchange property rights to scarce resources until they are fully allocated to the people who value them most. The key insights SL\&EM proponents take from the Coase theorem are (1) with low transaction costs individuals can bargain and trade their way to a competitive-like and surplusmaximizing outcome even in the absence of markets, and (2) where employment problems occur government regulation or labor unions are not the only or necessarily best option; rather, an alternative is to make existing markets more competitive by reducing transaction costs and creating new or better-protected property rights (Cooter and Ulen 2010).

The second line of thought also comes from Coase (1937) and the NIE. The argument is that firms, employment relationships, and internal labor markets come into existence in order to economize on the costs of allocating and coordinating resources through direct exchange in labor markets. That is, using managers to coordinate and allocate labor (employees) inside firms can be the more efficient solution when transaction costs of market exchange are relatively high. Since ILMs are coordinated by management and not demand/supply, one might think that considerable room therefore opens up for discrimination, exploitation and other maladies. 
However, these economists argue that competition in external labor and product markets in most cases effectively regulates and polices the practices and conditions of labor inside firms. They cite three reasons. The first is that workers can quit if they do not get market-going pay and conditions; a second is that firms lose profit if they do not adopt efficient employment structures and practices; and, third, even though explicit market prices do not exist in ILMs the managers and workers have substitute "shadow prices" (opportunity costs) to guide them toward outcomes that are surplus maximizing. Illustratively, Wachter and Wright (1990) argue that "ELM economic pressures on the ILM are not repealed; they are simply rechanneled...” (p. 244) and, hence, employers and employees are led to adopt efficient and self-enforcing contract practices and understandings that "serve the optimizing goals of the firm and the workers" (p. 242) and "promot[e] the joint surplus through savings on contract costs" (p. 256).

The point to be stressed is that the NE paradigm, either in terms of standard competitive price theory or a transaction cost efficient contract theory, does not rule out use of labor law per $s e$; rather, it creates a general presumption against interference. This position rests on other propositions that are implicit in the first welfare theorem and a mainstay of SL\&EM analysis the benefits of free trade and legal corollary of freedom of contract in competitive markets. The virtues of free trade and freedom of contract are that all sides gain from trade and resources flow to the contracting party who values them most (the core idea of the Coase theorem). Based on this reasoning, Frank Knight of the Chicago School comments, “All good economists since Smith have favored free trade, that is, laissez-faire against protectionism” (Emmett 1999: 439). From this perspective, the danger with labor law - and certainly with unions - is that despite their well-intentioned goals they often create undesirable protectionism and monopoly in labor markets. The free trade sentiment among NE economists is also captured in these comments by 
Charles Plott (2010). He states (p. 14), “[A] consensus [exists] within the scientific community that is spreading to the general public that free markets....are in everyone’s best interest.” He immediately cautions that "The principle [of free markets] does not say that government should do nothing” (p. 14) but also concludes in the next sentence that in free markets "there are natural tendencies and that the most productive policies are those that will harmonize with them.” These "harmonizing policies” are not zero regulation but regulation only when clearly needed, per his observation that "Our economy is built on the idea that competition can protect the consuming public” (p. 8). Members of SL\&EM would amend this statement only by expanding it to include the working public.

Hence, mainstream economists start-off analysis of labor law from the presumption that free trade in labor is desired; therefore, to make the case for an abridgement of free trade one must demonstrate clear evidence that markets for some reason are malfunctioning. That is, one must demonstrate market failure (Addison and Hirsch 1997; Boeri and van Ours 2008). A market failure, traditionally defined, arises when some feature of labor markets diverges in a substantively important way from the ideal of perfect competition. Oft-cited examples are monopsony, imperfect/asymmetric information, externalities, public goods, principal-agent problems, match-specific investments, and barriers to mobility. However, the extended efficient contract form of NE, as described above, has been able to demonstrate that many of these (alleged) departures from competition are not likely to pose significant social concern. One reason is that they often reflect an efficient adaptation to underlying technological and cost constraints (Dow 1997). For example, low turnover may not mean a firm has monopsony power but, rather, that workers choose to stay with the employer to reap the benefits of specific on-thejob training. Likewise, if women are mostly employed in a group of low-paying occupations 
while men are mostly employed in different group of high-paying occupations this is not necessarily a sign of discrimination but instead efficient sorting by comparative advantage (due to different biological endowments and gender-related tastes) and differences in human capital investment (due to different occupational choices and family roles). A second reason is that employers and employees are often able to create self-enforcing contract provisions and safeguards that protect themselves from potential opportunism and exploitation on account of these non-competitive elements. For example, match-specific investments (e.g., firm-specific job skills and training) create sunk costs for both the firm and worker and the two sides are therefore restrained from opportunistically taking advantage of each other by the prospect of losing these costs if the relationship ends. Wachter (2004) points out these contract safeguards are not always fully effective and are necessarily a second-best solution relative to a world of perfect competition, yet broadly viewed they are often first-best solutions in light of prevailing costs and constraints. He states:

"However, second-best solutions are not necessarily market failures that give rise to policy improvements. Information asymmetries, potential opportunism, and moral hazard are real economic costs just like any other economic cost, such as workers' insistence on being paid to work. Consequently, the self-enforcing arrangements worked out by the parties are arguably first-best, given the restricted set of solutions available to them” ( $p$. 169-70).

It is a fair generalization to say that economists associated with the SL\&EM are for these reasons predisposed to regard labor markets - absent compelling evidence to the contrary -- as approximately competitive and employment contracts as generally efficient (Mercuro and Medema 1997; Schwab 1997; Huang 2009). This leads them, in turn, to favor maximum scope for free markets, competition and private ordering in firms and, conversely, to take a skeptical "first show me the market failure" argument toward proposed extensions of labor law, government regulation, or trade unions and collective bargaining. Their minimalist view on labor 
law is then reinforced by practical considerations. That is, in an ideal world government regulation could potentially pinpoint instances of workplace exploitation or discrimination and fashion cost-effective remedies; in the real world, however, government regulation is slow, cumbersome and politically driven and therefore can entail very large costs for fixing a social problem. Society, therefore, may find that the costs from intervening in markets far outweighs the benefits.

\section{A Case Study: Posner's Economic Analysis of Law}

Exhibit A of the general approach I am describing is Richard Posner's Economic Analysis of Law (2007); the approach there is, in turn, mirrored in practically every other book and journal article with "law and economics" in the title. My purpose is to illustrate in a concrete way (1) reliance of the second L\&E movement on the competitive model and (2) the marked tendency of the model to yield "guilty until proven innocent" conclusions about labor law.

The title of Chapter 1 is "The Nature of Economic Reasoning." The first sentence reads, "This book is written in the conviction that economics is a powerful tool for analyzing a vast range of legal questions...” (p. 3). I highlight this sentence because it suggests that economics is a singular entity, mirroring the mainstream presumption à la Becker that there is only one corpus of economic theory (Becker is cited in footnote 1.1). The next sentence reads, “A student takes a course in price theory....” Price theory is another term for standard NE microeconomic theory, suggesting that while mainstream economics may indeed encompass a huge domain of nonstandard topics that the core remains the same price theory that earlier Chicagoans, such as Friedman and Stigler, popularized in a half century ago. The new L\&E innovation, however, is to treat legal rules as establishing another vector of prices facing economic agents. 
At the end of the first paragraph follows a new heading, labeled "Fundamental Concepts.” The first fundamental concept is "man is a rational utility maximizer” (p. 4). From this flows what Posner (p. 4) calls the "three fundamental principles of economics." The first is the law of demand (price and quantity are inversely related); the second is the economic meaning of cost (often measured by a market price but more generally by the economic value of resources devoted to an alternative use, called opportunity cost or shadow price); the third is that resources tend to gravitate toward their most valuable uses if voluntary exchange and market trading are allowed (markets tend to promote efficient outcomes).

These concepts are supplemented with three fundamental NE tools: the law of demand, illustrated by a downward sloping demand curve (Figure 1, p. 4); a competitive DS model of markets (Figure 2, p. 8); and the welfare criteria of Pareto superiority and the Kaldor-Hicks compensation principle. The next-to-ending section of Chapter 1 is devoted to "The Realism of Assumptions in Economics." Posner here follows Friedman (1953) and argues that the neoclassical theories and tools he uses are not to be judged by whether they are realistic (characterized as a demand on the part of critics for “descriptiveness completeness” (p. 16)) but by their predictive power. People have cognitive limitations (bounded rationality) and cannot as a factual matter make all the calculations competitive theory presumes; nonetheless, observed market outcomes typically approximate competitive predictions and therefore analysts may use the model "as if" it is a description of reality.

Posner only briefly examines the effect of government regulation on markets in Chapter 1. The specific example chosen -- rent control in a competitive housing market - illustrates the general points that regulation is frequently demanded by special interest groups as a form of rentseeking behavior, often has undesirable market consequences (shortages, higher prices, etc.), and 
entails an overall reduction in social welfare through resource misallocation and deadwight loss. Chapter 11 is devoted entirely to regulation of the employment relationship. Posner considers a number of staple topics in labor law: unions, employment-at-will, minimum wages, occupational safety and health, mandated benefits, discrimination, and pensions. Space precludes a detailed review of this chapter; I thus summarize below salient points, roughly following the order in the book.

- Labor markets are broadly competitive in nature since "labor monopsony.... is not a serious problem in this country" (p. 342) and "monopolies and cartels carry within them the seeds of their own destruction” (p. 343). Even where competition is not fully effective due to imperfect information or other frictions, one can nonetheless presume that labor outcomes are (mostly) efficient because otherwise unexploited gains from trade "would be negotiated voluntarily" (p. 349). The base-line for analysis, therefore, is “an efficient common law of labor relations” (p. 341).

- Unions act as a labor cartel and win higher wages for their members but at the cost of economic inefficiency and "reduction in the demand for labor caused by union wage scales” (p. 343). The National Labor Relations Act "is a kind of reverse Sherman Act, designed to encourage cartelization of labor markets” (p. 344).

- Workers were not victimized by early $20^{\text {th }}$ century “yellow-dog contracts” (a provision that says a worker agrees as a condition of employment to refrain from joining a labor union) because in a competitive labor market "the worker presumably would demand compensation for giving up his right to join a union” (p. 341).

- "Further evidence that job security is inefficient is that ....employment-at-will is the normal form of work contract in the United States. The worker can quit when he 
wants... An employer who gets a reputation for arbitrarily discharging employees will have to pay new employees a premium...” (p. 348).

- A legal minimum wage "reinforces the effect of unionization on wage rates" (p. 352) and thus represents another form of monopoly influence in labor markets; it also is ineffective in poverty reduction and most harms the job prospects of the workers who are most disadvantaged (e.g., black teenagers).

- “The Occupational Safety and Health Act .... is arguably superfluous. The employer has a selfish interest in providing the optimal.... level of worker health and safety” (p. 354).

- Women's lower wages relative to men are mostly due to their different human capital and occupational choice decisions, made in light of different family roles and preferences. These differences "would have narrowed even without government intervention" and "not all employment discrimination on grounds of sex is inefficient.” (p. 357).

- Pension protection may well not be necessary because (in part) “[t]he employer’s incentive to abuse the power that incomplete vesting conferred on him by reneging on his unwritten contract to deal fairly with his employees would be held in check by his concern for preserving a reputation for fair dealing” (p. 363-64).

I cite these examples from Posner's book to give concrete representation to what I am here calling the NE paradigm in the analysis of labor law and to its various properties and characteristics. One may also consult labor economists such as Boeri and van Oerts (2008) and legal scholars such as Jolls (2006) to see the same model and mode of reasoning in action. I 
believe it is clear that "assume a competitive labor market" is the starting point for this type of economic analysis of law and that the structure and operationalization of this theory -- either in perfectly competitive or extended “demand/supply with frictions” form - by its very nature leads to a guilty until proven innocent verdict on labor law. The entire point of this chapter, in turn, is to question whether this a priori negative-leaning verdict on labor law rests on solid and evenlybalanced theoretical ground.

\section{The Competitive Model in the First L\&E Movement}

IEIR economists do not deny “demand and supply;” further, they recognize that competition is often a beneficial force that protects and advances the conditions of labor and incents firms to efficiently produce goods and services for consumers. These are part of the success story of capitalism. However, IEIR economists also claim that there is a darker side to labor markets in capitalism that NE and the SL\&EM neglect, assume away, or fatalistically attribute to inexorable economic law. Craypo (1997) captures the IEIR viewpoint and critique of NE, for example, when he states,

"Institutional labor economics in America appeared before the turn of the century in response to neoclassical failure to study labor markets rather than labor theories and therefore to address chronic unemployment and low wages among hourly workers.... At the heart of the institutional perception.... is the conviction that society gets the labor market outcomes it wants, not those determined by some economic law, and that society therefore must assume a responsibly interventionist position.” (p. 231).

The term the early institutional economists gave to the darker side of the world of work is “labor problems" (also called "evils”) and many of the labor textbooks written by IEIR economists through the 1960s had the term "labor problems" somewhere in the title (e.g., 
Watkins 1922; Shultz and Coleman 1961). Commonly cited labor problems were poverty-level wages, long work hours, industrial accidents, child labor, and unemployment; the package of "visible hand" measures to solve these problems included labor law, collective bargaining, social safety net insurance programs, and counter-cyclical fiscal and monetary policies (Kaufman 1997, 2003a). As the old-style IEIR labor economics was replaced by new-style NE labor economics the term "labor problems" faded from sight and is today never encountered in the NE/SLEM literature. One may fairly speculate that part of the explanation is that the concept of labor problems carries a connotation of sub-optimality which goes against the maximization hypothesis central to NE/NIE theories; arguably another explanation is that the concept of labor problems provided IEIR economists with a rationale for government intervention in labor markets which NE/SL\&EM writers typically regard as unpersuasive and counter-productive.

The position of institutional economics and IEIR is that a laissez-faire or "state of nature" capitalist economy, such as in the early twentieth century United States, is certain to be unbalanced, unstable and inhumane and therefore conducive of considerable inefficiency, injustice and social conflict (Commons and Andrews 1916; Rutherford 2001; Budd 2004; Isaac 2007; Kaufman 2010b). The purpose of FL\&EM, accordingly, is to discover and implement labor law and the other policy measures in a manner that promotes greater balance, stability and social harmony. This does not mean IEIR economists have in mind a one-way street of evergreater regulation of labor markets; it does mean, however, that they think much of the labor legislation and regulation enacted over the twentieth century was on balance a good idea and has well-served the nation and, correlatively, it would be a mistake to dismantle large parts of it as counseled by the neoliberal and "first best" part of NE and SL\&EM (Osterman, Kochan, Locke and Piore 2001; Kochan 2005; Befort and Budd 2009). 
The difference of opinion between FL\&EM and SL\&EM revolves around different assessments of the benefits and costs of labor law, unions, and other such measures (compare Freeman and Medoff 1984 vs. Epstein, 1983; Craypo 1997 vs. Dow 1997; Kaufman 2010c vs. Neumark and Wascher 2008). NE and SL\&M see few if any benefits because they look at labor markets as highly competitive, put considerable faith in the invisible hand, and judge performance mostly (or solely) by the criterion of economic efficiency (Lazear 2000); on the other hand, they see large costs in the form of fewer jobs, less competitive industry, higher consumer prices, a larger government bureaucracy, and a less efficient allocation of resources.

IEIR, on the other hand, looks at labor law and associated employment programs and sees greater benefits and lower costs (e.g., Belman and Belzer 1997; Block, Roberts, and Clark 2003; Arthurs 2006; Traynor and Dau-Schmidt 2009; Estlund 2010). On the benefit side are six factors unduly discounted or neglected in NE:

- Frictions, impediments and market failures are inherent to and widespread in labor markets and, therefore, invisible hand forces are present but attenuated and unable to fully protect and advance the interests of labor.

- Labor markets and employment relationships are (in general) a tipped playing field favoring employers' (and consumers') interests over workers' because of built-in social, legal and economic inequalities; hence, employment outcomes may be “competitive” but also considerably unequal, inefficient, and socially undesirable.

- Competition in labor markets, more so that in product markets, can become excessive and actually retard rather than promote efficiency and industrial performance. 
- Firms often have market power to set wages and this opens up space for noncompetitive outcomes in employment relationships that may contain a significant element of discrimination, exploitation, or unfairness.

- Institutions in labor markets are not well-viewed as primarily inefficient wedges and distortions; rather, they are also essential to a high performing employment relationship because they promote higher static and dynamic efficiency through encouragement of cooperation and trust, organizational citizenship and loyalty, security of investment in training and hard work, and voice and involvement in problem-solving.

- Efficiency is important in evaluating employment outcomes but so are human rights for workers, democracy in the workplace, respect and fair treatment by employers, and jobs that are safe, satisfying and meaningful.

IEIR economists also believe the costs of labor law are not as large or serious as NE portrays. For example,

- Job losses are smaller (or not at all) for a moderate increase in labor costs from new or expanded employment law and regulation, in part because labor demand curves are more inelastic and "looser" due to non-NE features such as production indivisibilities and interdependencies (e.g., team forms of production; positive wage/effort effects).

- Labor law and regulation are often "distortion-correcting” rather than "distortioncreating” so at least over a range the efficiency costs of labor law emphasized in NE are minimal or non-existent. 
- Labor markets and firms frequently have resource slack and organizational buffers that can help absorb the cost effect of labor law.

- Unfairness, exclusion, and ill-treatment in employment procedures and outcomes generate many economic and social costs that NE omits or under-emphasizes (e.g., greater absenteeism, less work effort, more strikes, waste of human resources) and which labor law can help reduce.

- Government law and regulation can be administered more efficiently that NE portrays and, similarly, government leaders/workers are not just self-interested rent-seekers.

The FL\&EM has its roots in the 1880s and was much inspired by the HSE type of economics done in late nineteenth century Germany (Hovenkamp 1990; Pearson; 1997; Jacoby 2005); in the labor area it was also closely linked with the creation of the International Labor Organization (ILO) at the end of World War I (Kaufman 2004). The beginnings of industrialization brought with it numerous employment problems, mounting strikes and capitallabor conflict, and the rise of radical trade unions and socialist political parties. These individual problems became known collectively as “The Labor Problem.” The economists and fellow social reformers who started the FL\&EM believed that the Labor Problem, if allowed to fester and intensify, threatened the survival of American capitalism and democratic form of government (Fried 1998). They sought to defuse it by a middle-way program of reform that steered a course between laissez-faire on one side and socialism on the other.

Two economists are the fathers of FL\&EM, Richard Ely and Henry Carter Adams. Both did graduate work in Germany in the 1880s and wrote on the intersection of law and economics, particularly with regard to contracts and property rights (Rader 1966; Dorfman1969). Just as 
Walras (earlier quoted) enunciated certain themes that capture the essence of NE, Adams and Ely do the same for IEIR. I start with Adams.

Adams' presidential address to the American Economic Association is titled "Economics and Jurisprudence" (1897). Adams states that law is "the background of all associated activity; it provides the framework that limits and controls the exercise of liberty.... [and is] the expression of the ethical sense of a community crystallized about the problem of common living” (p. 138). The fundamental objective of law is to "understand justice,....explain the evolution of justice,.... and formulate those rules of conduct essential to the realization of justice.” (ibid.). Adams emphasizes justice as the chief goal of law because justice is a prerequisite for a stable and harmonious social order and such an order is, in turn, a prerequisite for a prosperous economy.

The major domestic problem Adams addresses in his paper is the Labor Problem. He says, "the workings of self-interest in the industrial field do not in all respects appear to be in harmony with the ideals of justice, and ..... it places in jeopardy material progress itself” (pp. 142-43). His diagnosis for the growing disharmony in society is that the structure of relations between employers and employees shifted in ways that considerably tipped the labor contract in favor of employers (e.g., the growth of labor corporations, a wage labor force dependent on employers for jobs and the means of production; substantial unemployment in labor markets); this growing inequality -- and the insecure and frequently oppressive employment experiences that accompanied it -- created a growing sense of individual and class injustice; and the solution, therefore, was to realign the legal order and set of property rights to achieve a better bargaining balance. Adams’ (1887: 90) referred to this process as “raising the plane of competitive action,” such as through new protective labor laws and growth of collective bargaining, with the idea that 
this does replace competition but raises the floor on competition so it yields more just outcomes and therefore more cooperation and harmony in industry and higher economic performance.

Ely's book The Labor Movement in America (1886) stands as the first work in what later became the American field of industrial relations. He argues that trade unions and labor law are required to "remove disadvantages under which the great mass of workingmen suffer, and must continue to suffer unless they get relief either by voluntary combination or by combined political action” (p. 96). He notes in the same paragraph that orthodox economists maintain that promoting free competition in labor markets protects and advances workers' interests but, he claims, this is a false view.

Ely cites two reasons for this fallacy. The first is the NE view that competition creates an open playing field where the ordinary worker can get ahead through individual action. In reality, legal, social and economic inequalities tip the contest in favor of employers and make it difficult for the mass of workers to escape from a life in dangerous, low paid, and onerous jobs. The result, therefore, is "absence of actual equality between the two parties to the labor-contract, and the one-sided determination of the price and other conditions of labor” (p. 100). The second reason is the NE view that labor is essentially similar to other commodities and free DS competition, therefore, leads to beneficial outcomes. Ely argues, however, that because labor is embodied in human beings competition in labor markets does not work as DS theory predicts. Fluctuation in wages and jobs makes workers feel insecure, demoralized, and antagonistic toward employers, all of which undercuts efficiency and harmony in the workplace. Similarly, competition in labor markets can be destabilizing - "If the demand falls, labor cannot be withdrawn from the market like other wares. On the contrary, .... the supply must increase by reason of competition of a greater number of laborers .... [as] children and women seek labor to 
eke out the father's income” (p. 101). And, finally, workers are forced by mobility costs and lack of alternative jobs to "risk health in ill-ventilated rooms... and [their] lives ....by [employers"] failure to fence in dangerous equipment” (p. 106).

In 1905 Ely took the lead in founding the American Association for Labor Legislation (AALL). The AALL soon became the most important research and lobbying group in the country for expanded labor law and social insurance programs (Moss 1996). The group actively promoted workmen's compensation, unemployment insurance, old age pensions, minimum wages, maximum hour limits, a ban on child labor, workplace safety legislation, universal health insurance, and counter-cyclical public works spending. A variety of economic and social arguments were advanced in favor of these measures. To illustrate I take two examples (Commons and Andrews 1916; Moss 1996; Kaufman 1997).

The first is workmen's compensation; that is, employer-financed payments out of a general fund to employees who have suffered loss of work due to a workplace accident. From an IEIR perspective, unregulated competition in labor markets leads to excessive injuries because workers possess poor information about safety risks and are often constrained from leaving unsafe jobs by mobility costs. On the employer side, firms often have small incentives to invest in safety because of a public goods problem (workers do not speak up about unsafe conditions out of fear of employer retaliation and therefore act as free riders in the hope someone else will do so) and the availability in most years of an ample supply of unemployed workers eager to replace the injured. Making employers pay an injury tax, therefore, gives them an incentive to improve safety; it forces employers to bear the cost of accidents as part of their total cost of production (rather than shift the cost to workers, families, or the community). And, finally, accident compensation is a humane and just payment to help unfortunate workers who because 
of a workplace accident can no longer work to put food on the table. Thus, labor law serves to increase both efficiency and fairness.

A second case is a legal minimum wage. It has a number of virtues that conventional economics mostly ignores. For example, a minimum wage puts a floor under labor markets and prevents sweatshop wages; stops a destabilizing fall in wages during recessions and depressions; provides an incentive to employers to improve operational efficiency, helps reduce income inequality; increases household income and aggregate demand in the economy; improves wages for the groups most exploited and discriminated against; draws people into the labor market and legitimate employment, and helps ensure that workers get at least a social minima of income. IEIR and the FL\&EM dominated intellectual thought and policy making on labor law into the 1960s and 1970s. High water markets were the Progressive era (1900-1914), the New Deal (1933-1945), and the New Frontier/Great Society period (1961-1968). Ely passed on the IEIR baton to his student and colleague at Wisconsin, John Commons. Commons, like Ely before him, was elected by his peers to be president of the American Economic Association (1917) and was widely recognized as the nation’s foremost labor economist. Commons was a tireless advocate for the AALL program of expanded labor law, social insurance, collective bargaining, and government counter-cyclical fiscal and monetary policy. Economist Kenneth Boulding (1957) declared Commons was, "the intellectual father of the New Deal, of labor legislation, of social security, of the whole movement in the country toward a welfare state” (p. 7).

A puzzling question from today’s neoliberal/SL\&EM perspective is this: how could Commons, presumptively considered by his peers to be a good economist, champion these interferences with the free market? The answer is that he considered but rejected the "assume a 
competitive labor market” proposition as a sound place (by itself) for theorizing and evaluating labor law. Illustratively, he stated, "The commodity theory of labor...is not false, it is incomplete” (Commons 1919: 17). Later he amplified on this, saying (Commons 1950),

Interference with the law of supply and demand has always been the main objection raised against all collective action, whether against protective tariffs, against immigration restriction, against labor unions, or against corporations; but these interferences have nonetheless been repeated and cumulated for a hundred years, because the alternatives of noninterference under the circumstances were deemed worse than the interferences. Public programs and policies cannot be evaluated in terms of logical consequences of isolated assumptions or similarities. They must be judged by the practical consequences of their operations. This requires a subtle balancing of many parts - some of which are necessarily contradictory (p. 137, italics added).

Note in the first italicized part of the quote the IEIR proposition that the costs associated with labor law intervention in markets are positive but less than the costs incurred from continued laissez-faire. In the second italicized part is another IEIR theme; in particular, that labor law cannot be considered in isolation of historical and social context but, rather, must be evaluated in terms of the conditions of the time, as part of a complete package (system) of industrial relations institutions and practices, with a goal of achieving economic and social balance, and recognition that not all parts of an industrial relations system can be made to smoothly work together.

Later generations of IEIR economists have staked-out the same position. I provide three examples. All three concern the case for unions and collective bargaining but the implications are identical for labor law. The first is Harry Millis, professor of economics at Chicago, president of the American Economic Association (1934), and a pre-WWII institutional-oriented economist. In testimony to Congress on the proposed National Labor Relations Act, he states (National Labor Relations Board 1985: 1553-54):

"Of course, if there were perfect mobility of labor, keen competition for labor, and no concerted control of wages and hours by employers, the situation would be substantially 
different from what it has been and the case for collective bargaining would be less conclusive in modern industry. I am aware that many of my academic brethren assume that these conditions just mentioned are generally true, and reason that in the absence of such friction in the market, wages, hours, and all the rest of it rather steadily adjust themselves to what industry, and consumers, should and can bear.”

But he then goes on to explain (pp. 1553-54),

The truth, as I see it, is ..... that the competitive demand for labor, while important, does not go far in protecting the workers against long hours, excessive overtime, fines, discharge, without sufficient cause, and objectionable working conditions.... One is thus driven to the conclusion that.... hours of work and conditions of work -- things which intimately concern workmen, are best decided collectively -- through legislation or through collective bargaining, and some of them are not easily subject to legislative control. This is particularly true of a reasonable degree of security of tenure. The case for collective bargaining is only less strong with respect to wages.

A second example is economist Lloyd Reynolds, a president of the Industrial Relations

Research Association (1955). He states (Reynolds 1954: 543) as a general principle, “[I]t is apparent that local labor markets in this country .... are not highly competitive.” He goes on to amplify on this observation (p. 549):

“Only in theory, then, does the 'competitive labor market' provide an alternative to wage determination through collective bargaining. The practical alternative is collective bargaining versus wage-setting by employers with rather weak competitive checks. Under non-union conditions, the immobility of the majority of workers plus the unsystematic selection of jobs by those in search of work gives employers wide latitude in determining wage rates and other conditions of employment. An employer can offer terms considerably below those generally prevailing in the area and still secure an adequate labor force. He is subject to serious competitive pressure mainly at the peak of business cycles, when job opportunities in other plants are relatively plentiful. Even after years of high unemployment, one still finds large differences in the wages offered by different employers for the same jobs.”

A third example of the IEIR perspective comes from John Dunlop. In an interview

published in 2002 (Kaufman 2002: 338) he states,

"I would surely agree that in some cases unions and collective bargaining have made wage rates uneconomic. This is undesirable. But I have several problems with the view you have just stated [the neoclassical critique of unions]. I reject out of hand any 
argument that the economy would be better off without unions. Unions do not come into the picture and distort some 'perfect' wage structure, because there is no such thing. In the real world there are all kinds of distortions and inequities built into the wage structure, as any person who has set wages knows. To assume in a model that wages are 'competitive' is to assume away a large part of the reality."

In an earlier essay, Dunlop explicitly takes the same position that Commons enunciated more than six decades earlier regarding the "assume a competitive labor market” proposition. That is, the model by itself is too narrow and simplistic to serve as an adequate tool for understanding labor markets and labor law. Thus, Dunlop (1984) declares, "the competitive model, or economic considerations alone, are not an adequate tool unassisted by.... industrial relations tools and concepts” (p. 23). Several years later “second-best” macroeconomist Robert Solow repeats the same theme: "It does not follow from any of this that the ordinary forces of supply and demand are irrelevant to the labor market, or that we can do without the textbook apparatus altogether. It only follows that they are incomplete and need completing” (Solow 1990: 22).

As reviewed earlier in this chapter, mainstream economists have in the last two-to-three decades substantially generalized and extended the competitive model and incorporated many frictions and imperfections, including the existence of hierarchical firms and structured internal labor markets. From an IEIR perspective, this is all to the good and helps bring NE and IEIR together toward a middle ground.

There remains, however, a divide along several dimensions. One is methodologicalbased. The way that many NE/NIE economists have incorporated labor market frictions and internal firm structures into standard DS theory is to add them as additional constraints in an optimization model (Becker 1976; Lazear 2000). By the nature of optimization, however, the resulting outcomes (e.g., unemployment because of job search costs; discrimination because of 
imperfect information) are efficient in the sense they cannot be improved upon (anything less, by definition, is not optimization). If, in turn, they cannot be improved upon, then evidently no opportunity exists in labor markets for labor law or unions to improve the situation. Hence, NE/NIE incorporates frictions and imperfections but in a way that still leads to (mostly) noninterventionist conclusions. Gregory Dow, in a review article of NIE, well articulates this situation. He explains (Dow 1997: 60),

"A great deal of intellectual effort has gone into the construction of economic rationales for existing organizational practices.... This reflects a tendency among most NIE writers to assume, at least prima facie, that actual employment practices represent efficient solutions to complex contracting problems. This efficiency assumption is useful in generating explanatory hypotheses of a functionalist kind (employment practice $\mathrm{X}$ exists because it satisfies efficiency criterion Y under environment conditions Z). However, it also places a heavy burden of proof on advocates of labor market regulation by obliging them to identify specific market failures that warrant government intervention. One must often read between the lines (and squint hard) in order to discover a rationale for regulatory policy in the NIE."

On one hand, IEIR recognizes we do not live in a perfect, frictionless world and therefore some employment problems are bound to arise as the nature of things. On the other hand, they also worry that this type of optimization modeling ends-up being an ex post rationalization; that is, if we observe it then it must be efficient (since people have an incentive to maximize joint surplus and exhaust gains from trade). They also believe it is impossible to explain many features of employment relationships as an efficient contract outcome of economizing behavior. Thus, Dunlop (1994) concludes that, "the new institutional economics has little to contribute....to an understanding of internal labor markets" (p. 395) and "It is an unacceptable position, in my view, to define an internal labor market simply as a 'set of explicit or implicit, more or less long-term agreements between a firm and its workers'.” 
The second divide concerns the role of inequality. The NE second welfare theorem (earlier described) asserts as a matter of theory that economic efficiency is separable from economic inequality; as a practical matter most work in SL\&EM does not actively give attention to inequality of outcomes on the argument that distributional fairness is an ethical and subjective matter and therefore not one amenable to economic analysis. Posner (2007: 14-15), for example, argues that economists cannot resolve normative debates over fairness but can generally agree on the more delimited normative goal of maximizing the value of output (i.e., attaining efficient outcomes). Work in the FL\&EM and institutional economics tradition, however, insists that a separation between distribution and efficiency is untenable on theory grounds because fairness is a fundamental determinant of workplace relations and therefore productivity and firm performance (e.g., Commons 1934; Akerlof 1990; Bewley 1999; Befort and Budd 2009). Further, distribution determines the location of the DS curves in the labor market diagram and whether wages and conditions of employment are high or low; this is particularly important for evaluating labor law since the size of compensating wage differentials that are relied on by SL\&EM to provide correct incentives to firms in matters such as workplace safety and fair treatment will themselves be high or low depending on distribution. Likewise, IEIR notes that efficiency also has an ethical and subjective dimension -- because it rests on opportunity costs that are a function of individual preferences and valuation -- and is in this respect on no firmer theoretical ground than fairness (Samuels and Schmid 1981). Finally, to put aside distributional fairness is to privilege the status quo of income and wealth in society.

A third divide concerns the relevant variables to be included in the social welfare function for evaluating public policy in general and labor law in particular (Budd and Scoville 2005; Gross and Compa 2009). Making maximum value of output the criterion privileges 
consumers' interests because they gain from abundant low priced goods but slights workers' interests because labor is in this framework treated as simply another factor input that should be given pay, conditions, and treatment no higher than the minimum the market allows. IEIR insists, on the other hand, that since labor is embodied in human beings that workers' interests in good pay, reasonable hours and conditions, and a satisfying work life need to also get explicit weight in the social welfare function for otherwise the material objects made in the economy are given higher priority than the human beings who make them (Kaufman 2005). Giving attention to workers' interests, in turn, means that efficiency in production has to be balanced with other workplace considerations that SL\&EM slights, such as human rights at work, democratic firm governance (e.g., due process, voice), and jobs that build-up the capabilities and character of the nation's people.

\section{IEIR Principles and Concepts}

Given this introduction, I want to move toward greater development and analytical representation of the theoretical framework used by IEIR/FL\&EM to examine and evaluate labor law and labor institutions. This builds on earlier work by this author (e.g., Kaufman 1997, 2003a, 2007a,b) and other relevant studies. A general overview of the institutional approach to L\&E is provided by Samuels and Schmid (1981) and Mercuro and Medema (1997). I proceed in a twostep process: first, delineation of key concepts and principles in this section and, second, in the next section a diagrammatic exposition. Certain points described above are reiterated for purposes of emphasis and inclusiveness. Also, certain complementary concepts and ideas of Coase and the NIE are brought over to IEIR. The list of IEIR principles given below starts with 
philosophical/normative underpinnings and then transitions to theoretical concepts and ideas important at the individual, firm and economy level.

Purpose of an economy. The purpose of an economy is to serve human ends. One way it does this is to operate efficiently so people have the maximum of goods and services. But the grand objective of human existence is not efficiency (the "largest GDP”) but the "good life" (Slichter 1931). What exactly constitutes the good life is subject to debate, but it certainly includes greater amounts of economic security, procedural and distributive justice, and opportunities for self-development and self-actualization than are provided by the efficiency criterion alone (Budd 2004; Sunstein 2004). IEIR proponents agree that economic policy should seek to get society on the production possibility frontier but only if the "goods" (or "social wealth”) included in calculating the frontier include not just GDP-type goods but also goods such as economic security, social justice, fulfilling jobs and healthful working conditions. Without this broader perspective, the interests of people (including workers) get subordinated by a narrow efficiency/materialist welfare objective to doing what is best for the economy, rather than structuring and operating the economy to benefit people.

Liberty. The NE version of liberty is negative liberty - i.e., absence of restraint - which leads these economists to advocate minimal government market regulation. From an IEIR perspective, however, "liberty to starve" or "liberty to work a fourteen hour day" is not an attractive conception of liberty; likewise, to say that both a poor person and rich person have an equal freedom to quit a dangerous or dirty job if they do not like it greatly empties the concept of freedom of meaningful significance (Adams 1897; Samuels, Medema and Schmid 1997; Fried 1998). Seen in this light, freedom of contract may be a façade that hides the whip of economic coercion wielded by one person with control of strategic resources (e.g., an employer offering 
scarce job opportunities) over another person who has few resources and must trade or go hungry (e.g., an employee with dependent family members and no alternatives source of income). Proponents of IEIR, therefore, base their theory and policy program on a concept of positive liberty. Each person has positive liberty when they have the resources needed to command the essentials of life, thus giving them not only the legal space to construct their life but also the economic space (Sen 1999).

Labor is Human. In NE labor is modeled as not substantively different from other factor inputs or goods and services and, hence, labor markets are also modeled as not substantively different from other kinds of markets (Addison and Hirsch 1997). Further, from a welfare perspective labor is solely considered as a factor input that does not itself count in social welfare but rather contributes to welfare only to the extent it is efficiently used to produce final goods and services for consumers. In IEIR explicit recognition is given to the fact that labor services are embodied in human beings (Commons and Andrews 1916; Budd 2004; Kaufman 2010b). This fact, it is maintained, fundamentally changes theorizing about labor; it also calls attention to the fact that if the goal of an economy is to improve human welfare then people's welfare as workers should be given consideration above and beyond their contribution to production and satisfaction of consumers' interests.

Behavioral/Social Model of the Human Agent. People are modeled as largely purposeful and self-interested, but decision-making is subject to bounded rationality and behavior is influenced by emotions, social interdependencies, and ethical precepts (Jolls, Sunstein, and Thaler 1998; Kaufman 1999; Schmid 2004). A key part of bounded rationality is that many future events are subject to fundamental uncertainty -- that is, cannot be represented by even a probability distribution; another key part is the distorting effect imparted to behavior 
by emotions such as anger, hate, love and pride. The first feature means that when fundamental uncertainty enters into decision-making human beings cannot even hypothetically solve a maximization model since the choice set is not well-defined; the second means that rational calculation is partly or wholly displaced and other non-logical motives dominate decisionmaking.

Transactions and Transaction Cost. A transaction is a legal transfer of ownership; transaction cost is the real resources used to effectuate and enforce this transfer (Commons 1934; Coase 1937).

Ownership and property rights. Institutional economics is built on the concept of ownership and correlative concept of property rights, per the statement of Commons (1934: 5) that "ownership becomes the foundation of institutional economics." Property rights also figure prominently in the NIE (Coase 1992; Furubotn and Richter 2005). Without prior specification of property rights and ownership fundamental economic constructs such as commodities, production functions, and demand and supply curves have no basis. These property rights also include not only ownership of economic goods but fundamental human and social rights.

Institutions. Institutions are bodies of rules, both formal and informal and explicit and tacit, that are built out of property rights (broadly defined) and define the rules of the economic game and the constraints, opportunity sets, incentives, and strategic interdependencies faced by economic agents (Commons 1934; Coase 1992; Groenewegen, Spithoven, and Van Den Berg 2010). All economic activity is "institutional" since its takes place within and is structured and guided by human-made institutions; it is also inextricably linked to concerns of fairness and 
status since the laws, rules, norms and customs created and enforced by institutions serve in part to apportion justice and social standing.

The Employment Relationship: Workers most often provide labor services in an institution called the employment relationship (ER). Unlike competitive goods markets, the buyer and seller of labor are embedded in a personal, long term, and socially interdependent relationship where many things besides price mediate and coordinate the exchange (Dunlop 1994; Befort and Budd 2009). It is also essential to recognize that the employment contract is a rental agreement for labor services.

Incomplete Employment Contracts: Because of bounded rationality, imperfect and asymmetric information, fundamental uncertainty, and the interdependent and complex nature of production tasks, transaction cost is both positive and large in most ERs. As a result, employment contracts are necessarily incomplete, contingent and open-ended and subject to numerous forms of externality, public good, moral hazard, opportunism, principal-agent problem, and tacit bargaining (Simon 1951; Marsden 1999).

Labor Time vs. Labor Power. Because of the incomplete nature of employment contracts it is necessary to distinguish between labor time and labor power (Thompson and Newsome 2004; Kaufman 2010b). Labor time is the sixty minutes that workers are required to be on the employers' premises in return for the hourly wage; labor power is the amount of work (physical, mental and emotional effort) the employees do during the sixty minutes to produce goods and services. The goal of firms is to extract the maximum labor power for the minimum of cost and push-back; the goal of workers is to get the highest return for their labor power with a reasonable limit on the maximum amount of labor power to be delivered. In some branches of IEIR the extraction of labor power is called the labor process, in others it is called the 
wage/effort bargain (Baldamus 1961).The labor process and wage/effort bargain create an inherent, if partial, conflict of interest in the employment relationship. They also set up a Prisoner’s Dilemma-type bargaining game (Miller 1991) where there is the possibility of a winwin outcome (employees provide high labor power; employers provide good paying secure jobs) but also a strong built-in tendency for emergence of a win-lose (or even lose-lose) outcome as one or both parties follow short-term self-interest and opportunistically take advantage of the other (e.g., employees provide high labor power; employers lay-off surplus workers). Employers create a human resource management system for the purpose of maximizing extracted labor power through a variety of control, supervisory and disciplinary devices (Edwards 1979; Edwards 2009).

Cooperation, Trust, Fairness and Job Security: Production is in most cases an interdependent process that requires active cooperation among workers and managers. The degree of cooperation (including work effort) is a choice variable for workers; low cooperation typically means low productivity and profits and high cooperation means the reverse. Many factors influence workers' willingness to cooperate but among the most important are trust, fairness and job security (Akerlof 1990: Budd 2004). Because of the Prisoner Dilemma nature of the ER, absent a spirit of trust, fairness, and shared rewards one or both parties easily gravitate toward the non-cooperation/low productivity option (Miller 1991; Schmid 2004).

Modes of coordination. Economies have alternative institutional modes for coordinating transactions; the two most important for theory are (1) markets and price, and (2) organizations and command (Williamson 1985; Coase 1992; Kaufman 2003b; Groenewegen, Spithoven and Van Den Berg 2010). 
Power. Power is the ability to satisfy one's desires and obtain a greater share of an institution's scarce goods (material and non-material). Power is influenced by how greatly an economic agent needs/wants an outcome and how long the agent can hold out in the bargaining vis a vis the other side (Samuels, Medema and Schmid 1997).

Imperfect Competition: Labor markets are by their nature not only imperfect (in the economist's sense) but among the most imperfect in the economy (Lester 1941; Thurow 1983). Competitive forces are present and the demand/supply model has some degree of explanatory power; nonetheless, in the short-medium run most labor markets exhibit substantial wage rigidity, constraints on labor mobility, and in most years excess labor supply (involuntary unemployment). These conditions mean labor markets are not self-regulating via flexible wages and are therefore partially coordinated by other means (e.g., labor quantity and quality adjustments); likewise, market outcomes may depart widely from competitive or efficient contract predictions and, in particular, conditions of discrimination, exploitation, and unfair treatment have significant space to emerge and persist in employment relationships.

Segmented Labor Markets: Labor markets are divided into segments more complex and variegated than the standard competitive versus monopsony categories (Kerr 1977; Dunlop 1994). Segmentation arises from factors that impede competitive forces and the flow of labor across firms and markets, including institutional rules (e.g., seniority systems, occupational licensing), different educational requirements, firm-specific skills, discrimination and social norms, and job search costs and the human desire for security. Segmentation impedes and replaces competitive DS forces; hence, wage rates and other terms and conditions of employment exhibit considerable diversity across firms and market segments. Some elements of this 
dispersion are equalizing (or "compensating" in the competitive sense) but many others are nonequalizing.

Internal Labor Markets: A major form of segmentation is the internal labor market (Doeringer and Piore 1971; Osterman 1987; Dunlop 1994). Firms create ILMs because they contribute to greater productivity and profit (e.g., by coordinating and controlling labor power and upgrading skills) and positive employee relations; they therefore have a strong efficiency rationale. They are also a major instrument for controlling/coordinating labor power. ILMs, however, also partially supplant and replace coordination via competition and market forces with management command and administration. ILMs are embedded in a hierarchical system of management power and authority and market forces and the quit option provide workers with only partial protection, particularly with regard to items not easily divisible and fungible into money (e.g., collective aspects of working conditions and treatment).

Inequality of Bargaining Power: Employers both individually and as a group have a power advantage over individual workers in both external wage bargaining and internal firm governance due to their legal authority over work (the "master-servant relationship"), control of the supply of jobs, the perishability of labor services (inability to inventory), workers' limited hold-out ability (from limited financial reserves, significant fixed costs of family subsistence), costly job search and restricted job opportunities, and tilted legal rules and resource endowments Commons and Andrews 1916; Kaufman 2010c). These conditions create a "tipped playing field" both "within the market" and "before the market" that favor firms' interests in exchange and governance relationships, thus allowing employers to capture a disproportionate and possibly unjust/unreasonable share of economic surplus, workplace control, and life satisfaction. 
Sovereignty. Economics is always "political economy" because the institutions and their derivative rules which guide and structure economic activity are in part determined through a political process in which people individually and collectively seek to capture and use the power of sovereignty to shape the institutions and rules to promote their interests (Commons 1950).

Reasonable value. Economic agents individually and collectively have a notion of what is fair and reasonable; whenever an outcome/process falls outside the bound of reasonableness they undertake action to alter the institutional matrix of rules and rights (Adams, 1897; Commons 1934; Mercuro and Medema 1997; McIntyre and Ramstad 2002).

Say's Law and Under-Consumption: For all the reasons cited, flexible wages cannot and do not act as an effective equilibrating mechanism in all but perhaps the very long-run, contrary to the macroeconomic principle known as Say's Law. Rather, labor markets often remain out of equilibrium (in the sense of a demand/supply imbalance) for months and years and restoration of equilibrium comes about as much from labor quantity and quality adjustment (e.g., demand/supply curve shifts) as from wage adjustment. Wage adjustments are slow, not because of unions or minimum wage laws - the usual parties blamed in NE - but because firms try to avoid cutting wages knowing that worker morale and productivity fall as a result (Bewley 1999; Fehr and Falk 1999). At a macro level, even with completely flexible wages the aggregate labor market is not self-correcting since wage cuts reduce household income and aggregate demand and, hence, cause production and employment to depart even further from full-employment equilibrium (Keynes 1936; Levendis 2007). Likewise, a free market economy is prone to underconsumption in the medium-to-long run because the bulk of the fruits of productivity growth are distributed to a relatively small group in the top part of the income distribution who have more 
inelastic labor supply curves (due to scarcity of unique talents, skills, positions) and thus reap a proportionately large part of real wage gains from economic growth (e.g., CEOs).

\section{Analytical Framework: An IEIR Model of Labor Markets}

This section puts these general principles into an analytical framework, shown in Figure 2. This model of labor markets has five parts. I describe them in order here, in the next section set them in motion to explain labor/employment outcomes, and then in the final section consider the model's implications for labor law both past and present.

The base-line economy represented by this model is free market capitalism without labor law, trade unions, social safety net programs, or macroeconomic guidance - in other words, something close to the American labor market in the early 1900s when FL\&EM took shape (Fishback 1998; Kaufman 2008). Applications to today’s economy are then sketched.

[Insert Figure 2 about here]

First panel (a). It has numerous distinguishing features. The area of the pentagon shape represents the size of GDP, usually represented in NE by a pie diagram. Part of the annual GDP has to go toward reproduction of the system -- that is, a minimum necessary amount to replenish capital, maintain the fertility of the land, and feed and clothe the workforce. Sometimes the reproduction level for labor is called the "social minima" or "social wage." The remainder of the GDP is available as a surplus or "discretionary income” that can be distributed to alternative uses and people; for example, it may be distributed as wages or profit or used for consumption, capital accumulation, or defense. The area under the horizontal dashed line represents the reproduction part of GDP, the part above it is the economic surplus (Davis 1992). The process of economic growth expands the pentagon shape and the size of the surplus; it contracts during recessions and depressions. The reproduction amount of GDP also grows over time, partly to cover greater 
capital depreciation and also because labor's social minima is in part culturally and historically conditioned. For example, the social minima in real terms is greater in 2000 than 1900 because of higher needs and expectations regarding education, health care, and housing.

The pentagon shape also represents the institutional infrastructure that coordinates and regulates the economy; it is the human-created command and control function. Institutional economists call it the governance system (Commons 1950; Williamson 1985). The pentagon shape captures five important IEIR ideas.

The first is that all economic activity is embedded in an institutional infrastructure of laws, property rights, and social relations that collectively set the rules of the game, the endowments of the actors, and the objectives they pursue (Mercuro and Medema 1997; Deakin and Wilkinson 2005). These factors determine whether markets exist, their structure and operation, and outcomes of DS. This idea is illustrated in panel (a) where the labor market and DS are surrounded by and embedded within this pentagon-shaped institutional infrastructure, also called in American IR the "web of rules” (Kerr and Siegel 1955; Dunlop 1958). The institutional infrastructure is taken as a "given" in NE microeconomics and, for most purposes, omitted from consideration (e.g., it is an invisible, passive, and status quo condition in Figure 1).

The second idea is that the institutional order is politically determined through some social choice process (e.g., dictatorship, monarchy, democracy) and contending factions and classes endeavor to use the power of sovereignty so as to shape the rules of the game to promote their interests (Samuels and Schmid 1981). Here is represented the political economy dimension of IEIR. A frequent argument in SL\&EM is that the common law evolves to promote efficiency and groups wanting to displace the common law with legislated labor law are often engaged in non-productive rent-seeking. This is a common charge leveled against the political activity of 
labor unions, for example (Epstein 1983). IEIR, however, argues that the common law refracts the constellation of political power in society and evolves through political contestation between insiders and outsiders (Mercuro and Medema 1997). It is important to ask, therefore: whose interests are being served by wealth maximization and is society satisfied with the resulting distribution of income and wealth? These questions are not answered by neutral economic law but by the governance structure that sets endowments and rules of the game. The reasonableness of economic outcomes, therefore, hinges critically on the distribution of power in society and whether its political and social institutions are open and egalitarian or segmented and oligarchic. If the latter, then what may look to NE as rent-seeking looks to IEIR as a social reform movement led by progressive groups such as trade unions on behalf of disadvantaged outsiders demanding equal rights - be they workers' rights for protection from unfair dismissal, women's rights for equal pay, African-American's rights for a discrimination-free workplace, or gaylesbian rights for employment regardless of sexual preference.

The third idea is that as a command and control system the institutional infrastructure inherently creates asymmetric power and authority relations where a relatively small group at the top of the pentagon are power-holders and order-givers and a much larger group toward the bottom have little power and follow orders. Since competition in labor markets is attenuated, they cannot provide a complete check and balance to the exercise of power and authority and, accordingly, society must ensure that the governance structure meets reasonable standards for due process, voice and representation. In IEIR this was historically expressed as a demand for industrial democracy (Webb and Webb 1897; Derber 1970).

The fourth idea is that the economy is not a natural law-like mechanism where some unseen gravity-like invisible hand automatically and without friction coordinates economic 
activity to an a-historical equilibrium but, rather, is an organic human-made structure that evolves over time as the institutional infrastructure evolves and depends on not only impersonal market forces for coordination but also the visible hand of administration, governance, management and planning (Commons 1935; Galbraith 1967; Chandler 1977; Rutherford 2001).

The fifth is that the pentagon-shaped governance system applies not only at the macro level of the economy but also at the micro level of the firm. That is, the NE firm exists as a technological production function and an invisible entrepreneur operates it by changing the mix of factor inputs in response to shifting market prices. In branches of the NIE, firms are a locus of efficient contracts that get adjusted in a similar manner to changing market and shadow prices (Furubotn and Richter 2005). In IEIR and other branches of NIE, on the other hand, the firm is a politically constructed entity with a property rights regime and hierarchy of power that is coordinated through a visible hand process of administration, management, planning and strategic choice by a chief executive officer, descending order of vice-presidents and directors, and various line and staff managers (e.g., human resource managers). The pentagon, invisible in the NE theory of the firm, creates an internal labor market (ILM) and where HRM acts as a "ministry of labor" and through central planning sets pay rates and assigns jobs (Doeringer and Piore 1971; Rubery and Grimshaw 1998). This process is broadly constrained by competitive forces in the ELM, but not deterministically so.

Panel (a) shows two sets of demand-supply curves, a set of pencil-thin lines and a set of broad bands. The former represent DS in the competitive model (as earlier depicted in Figure 1) and the latter represent DS in the IEIR model. A detailed explanation is provided shortly. Panel (b) takes the DS bands from panel (a) and adds two further features. The first is that the bandlike nature of the DS functions creates an area of indeterminacy in wages and other terms and 
conditions of employment, illustrated in the diagram by the bell-shaped curve. The idea is that organizational and institutional frictions partially obstruct competitive forces and therefore give individual firms some discretion regarding the wages and conditions they provide (Lester 1952; Dunlop 1957). The average wage in the market is $\mathrm{W}_{1}$; it is bounded, however, by a dispersion ranging from $\mathrm{W}_{2}$ at the highest wage firm to $\mathrm{W}_{3}$ at the lowest wage firm. The size of the area of indeterminacy may narrow somewhat in the long run but it tends to have considerable persistence.

Panel (b) also depicts the labor supply curve facing the typical individual firm in this market. In the competitive model the firm has a perfectly elastic (horizontal) labor supply curve (not illustrated in Figures 1 or 2), showing that the firm pays whatever is the market wage. IEIR argues, however, that the firm's labor supply curve typically resembles the kinked line EF. Assume this firm is paying the average market wage $\mathrm{W}_{1}$ and has hired $\mathrm{L}_{2}$ workers. The kinked supply function shows three things: first, the firm can pay infra-marginal workers a wage lower than $\mathrm{W}_{1}$ (the downward sloping portion) and many of its employees will stay with their jobs. Hence, the firm has some monopsony power (Manning 2003; Erickson and Mitchell 2008). Second, the firm can modestly expand its workforce with new hires of roughly the same effective labor at the prevailing rate of average hourly earnings. This is depicted by the horizontal segment of the supply line, the length of which is partly determined by the amount of involuntary unemployment in the local labor market. Past some certain point, however, additional workforce expansion necessitates either a higher money wage or, what is the same thing in production cost terms, hiring new people who bring to the job a lower level of effective labor (e.g., less skills or desirable work habits). In this range the firm's labor supply function is upward sloping, as in monopsony. 
Panel (c) of Figure 2 introduces the macroeconomic dimension of the employment relationship. NE has no need to feature such a model in Figure 1 because it assumes flexible prices and the invisible hand automatically steer labor markets and the aggregate economy to an equilibrium position of full employment via Say's Law. IEIR, however, claims that an economy has no such automatic tendency toward full employment and, indeed, the base-line condition is persistent excess supply of labor (Atkinson and Oleson 1998). A convenient representation of the IEIR position is the "Keynesian cross" model. Aggregate demand determines the level of output and employment, given by the intersection of the $\mathrm{C}+\mathrm{I}+\mathrm{G}$ schedule (consumption + investment + government spending) and the aggregate supply line (45 degree line). The full employment level of GDP is $\mathrm{Q}_{1}$ but in most years the economy suffers from insufficient aggregate demand and hence an actual output of only $\mathrm{Q}_{2}$ with consequent overhang of unemployment in the labor market. Market forces do not eliminate the excess labor supply, partly because wages have a large degree of rigidity and partly because a fall in wages reduces purchasing power and therefore further reduces aggregate demand and employment.

Panel (d) captures the IEIR distinction between labor time and labor power. Pictured there are two short-run production functions; they show how output increases with additional labor input (holding capital constant). In NE the economy has one unique output curve, such as the dashed line. The reason is that NE treats labor as a homogeneous commodity that generates a well-defined marginal product in a technologically determined production process. Thus, for a given labor input level $\mathrm{L}_{2}$ output is a single-valued number, such as $\mathrm{Q}_{2}\left(\mathrm{Q}_{2}\right.$ corresponding, in turn, to $\mathrm{Q}_{2}$ in panel (c)). At full employment the maximum labor input is $\mathrm{L}_{1}$ and the $\mathrm{NE}$ production function predicts a single-valued output of $\mathrm{Q}_{1}$. 
In IEIR, on the other hand, what the employer buys is $\mathrm{L}_{2}$ amount of labor time but the amount of output produced is a function of the amount of labor power obtained. The result is that in panel (d) a purchased amount of labor time $\mathrm{L}_{2}$ can yield a wide range of different labor powers, depending on the outcome of the wage/effort bargain and the extraction effectiveness of the employer's HRM program. The solid line production function shows that the maximum attainable labor power is $\mathrm{Q}_{3}$; the shaded area under this line shows all the other feasible levels of labor power. The employer who buys $\mathrm{L}_{2}$ units of labor time may get zero labor power (a point on the horizontal axis) if, for example, the workers stage a spontaneous walk-out or are all asleep in their trucks.

Panel (e) illustrates a pay-off matrix of employment relations outcomes. It represents the Prisoner's Dilemma nature of the ER. Employers and employees, respectively, can either choose to cooperate with each other or defect from the relationship and pursue narrow self-interest. This choice set creates the pay-off matrix shown in the diagram where the employment relationship can take one of four possible outcomes for the employer and employees: lose/lose, win/lose, lose/win, and win/win.

\section{IEIR Model in Action: How Labor Markets Really Work}

The next step is to put these diagrams into action to analyze how labor markets and employment relationships work and the nature of the outcomes they generate. The end product is a portrait of the employment world considerably different than one gets from "assume a competitive labor market,” with correspondingly different implications for labor law.

An employment relationship presumes as a matter of definition that firms have at least two people, a boss and worker. Coase (1937) and the NIE have explained that this agglomeration 
into a firm arises only if transaction cost is positive; the implication, therefore, is that in a situation of zero transaction cost all the firms disagglomerate to single person proprietorships and independent contractors. They have not, however, carried this insight to its logical conclusion (Kaufman 2010b).

With zero transaction cost the entire GDP in panel (a) is produced by single person firms. In this case, however, the economy has no need for a labor market or employment relationship since firms get labor services from other single person firms in product markets. An implication of Coasean logic, therefore, is that the DS diagram in panel (a) actually represents buying and selling of labor services in product markets, not labor markets. That is, rather than go to a labor market and hire Joe Smith to be an employee truck driver the firm goes to a product market and hires Joe Smith Trucking, Inc. to provide the service (Joe can get the funds to buy the truck since capital markets are also competitive). Without labor markets, however, the DS diagram in our Figure 1 (and Posner’s Figure 1.2) -- the core representation of “assume a competitive labor market” in NE and SL\&EM and the core theoretical device that drives their analysis of labor law -- disappears and has no coherent theoretical existence. The reason is that the competitive labor DS model implicitly assumes zero transaction cost and therefore frictionless trade and complete contracts; if these conditions exist, however, hiring employees in order to gain the legal right to direct/control their labor has no economic rationale since all performance requirements can be written into a complete sales contract and enforced at zero cost (Dow 1997).

Taking the logic in reverse, multi-person firms, labor markets, and an employment relationship only exist with positive transaction cost. But positive transaction cost arises from market frictions (e.g., bounded rationality, uncertainty, imperfect information); hence, the implication is that labor markets are always and everywhere imperfectly competitive. If labor 
markets are imperfectly competitive, however, the first welfare theorem is no longer applicable and, hence, one cannot presume that market outcomes are efficient. Further, by the theory of the second best (Lipsey and Lancaster 1956) one cannot presume that selective re-engineering of labor markets to make them more competitive will actually improve efficiency (it may worsen). The production of the nation's GDP in panel (a), therefore, takes place in a mixed economy with a combination of markets and firms and price and planning coordination. Competitive forces are present but necessarily attenuated and therefore offer only partial protection to employees.

Critics of the IEIR position may object at this point that more deeply examined this alleged "labor problem” (e.g., an area of indeterminacy in wages with attenuated competition) is not a problem in any substantive sense and therefore employees have no need of labor law protection. Such an argument, as earlier explained, is likely to invoke one or a combination of two arguments (Mercuro and Medema 1997; Dow 1997). The first is that alleged anomalies in labor markets, such as dispersed wage rates and costs of job mobility, are themselves rational economizing outcomes in the face of various costs and constraints not included in the simple competitive model (e.g., imperfect information); the second is that these observed labor market outcomes can be assumed on prima facie grounds to approximate efficient outcomes since, if they are not, economic agents have incentives to modify arrangements in order to capture additional gains from trade. As indicated earlier, IEIR does not completely discount these arguments; however, IEIR also believes they carry the danger of turning into tautology and an apologia for the status quo. That is, what significant labor market anomaly cannot be explained as an economizing outcome and, if the answer is none or close thereto (noting here that Becker (1976) claims the extended NE model can explain all human behavior in market and non-market contexts), then doesn't NE/NIE theory become a vehicle for an efficiency rationalization of 
whatever is observed? Opinions differ on this matter; the position of IEIR, however, is that labor markets and employment relationships are imperfect in a substantively important market failure sense and these imperfections open-up space in economic relations for labor law and labor institutions to do good as well as harm.

The merits of the IEIR case for labor law are strengthened by giving further consideration to the ramifications of positive transaction cost in labor markets. As explained above, the pencilthin DS lines in panel (a) have no logical existence; hence, the labor market cannot determine an equilibrium wage and set of terms and conditions. Instead, the DS lines are replaced in panels (a) and (b) by DS bands. On the demand side, this change is a logical outcome of the indeterminate nature of the wage/effort bargain in the labor process in panel (d). That is, the amount of labor time purchased is determinate but the amount of labor power and the size of the marginal product is uncertain and takes a range of possible values (Kaufman 2010a). Imperfect information and job search costs make the labor supply curve a band.

The indeterminate nature of the labor demand curve means that the law of demand does not locally hold; for example, a modest rise in the minimum wage may not cause a decline in employment (Doucoliagos and Stanley 2008). Likewise, employers have some discretion regarding the wage and conditions they provide and the threat of exit by workers is only partially effective in determining employers' HRM and employee relations practices. These implications are reinforced when panel (b) is considered.

The rising portion of firms' labor supply curve gives them some degree of monopsony power over inframarginal employees (because of mobility costs for workers if they quit). Monopsony power, in turn, means that firms gain the upper hand in wage bargaining and can practice some degree of labor exploitation (underpayment of workers). In the IEIR theory of 
labor markets, nearly all firms have some degree of potential monopsony power. Some do not exercise it because in panel (d) they know it will harm employee morale and result in lower productivity and in panel (e) doing so will undermine a win-win employment relationship (Bronfenbrenner 1956); others selectively exercise it as (say) salary compression for long-service but immobile employees, while others - often among the employers following a low-road HRM strategy or in firms were production is not much affected by positive employee feelings - use their monopsony power to practice labor exploitation in a number of ways ranging from low wages to work intensification to abuse of civil liberties and human rights (Shulman 2003).

The ubiquity of monospony (because labor markets are always and everywhere imperfect) also calls into doubt the logical coherence of yet another key component of SL\&EM the neoclassical labor demand curve. Standard price theory shows that an imperfectly competitive firm in the product market does not have a well-defined supply curve; for similar reasons firms in imperfectly competitive labor markets do not have well-defined labor demand curves (Fleischer and Kniesner 1980). Thus, the DS diagram and the standard labor demand curve diagram (e.g., Posner's Figure 1.1) - the two most important theoretical constructs that SL\&EM uses to make inferences about labor law - are both logically defective and need to be replaced by an alternative model. The IEIR solution is depicted in panels (a) and (b); that is, to replace the labor demand curve line with a labor demand curve band. The band idea illustrates absence of a one-to-one correspondence between the wage rate and quantity demanded of labor (as with a conventional NE labor demand line) yet allows for an inverse relation for relatively large wage changes. Thus, a modest and phased-in increase in the minimum wage may have no negative employment effect -- it may even be positive (Card and Krueger 1995) -- while a large one-time increase is more likely to have a negative effect. 
Not only do the DS curves change from lines to bands, their location also changes. This is represented in panel (a) where both bands are shifted down relative to the NE lines. The labor demand curve is shifted down (to the left) because in the macroeconomy pictured in panel (c) the economy typically suffers from insufficient aggregate demand; less demand for economy's products, therefore, means a smaller derived demand for its labor. Likewise, the labor supply curve is shifted down (to the right) because the employer class (and associated property/power elites) use their dominant political influence to create an institutional infrastructure that in various ways puts workers in a weaker bargaining position, forcing them to offer their labor time at a lower wage. For example, in a laissez-faire labor market dominated by employer interests (perhaps facilitated by restrictive suffrage rights in the polity and the financial corruption of the legislative process), the state provides no unemployment insurance. This reduces workers' holdout ability and forces them to lower their reservation wage to quickly get work, thus shifting the labor supply curve rightward (Fehr and Falk 2006). Similarly, employers use their power to get employment law written so it favors their bargaining power by creating an unequal relationship of "master and servant” with authority to terminate workers at-will (Deakin and Wilkinson 2005). The macroeconomic overhang of unemployed workers also forces down workers' reservations wages and induces them to provide more effort (Bowles and Boyer 1988).

Yet another change in the DS model regards the shape of the labor supply curve near the reproduction level of wages. NE theory draws the labor supply curve forward-sloped throughout, implying that as wages fall workers substitute from market work to other now-cheaper activities, such as leisure, attending school, and raising children. The theory does not explain, however, where workers get the income for food, shelter and family care if they do not have a paycheck. This consideration becomes paramount as wages approach or go below the reproduction (social 
minima) level because without a modern welfare state and social safety net programs to provide non-labor income the average worker is in a "work or starve" situation and has no choice but to get work at any price. Hence, the labor supply curve at low wages is kinked and develops a negative sloped (forward-falling) segment with considerable elasticity (not depicted in Figure 2 to avoid cluttering the diagrams), showing that as the wage goes below the subsistence level workers and family members increase offered labor supply in order to collectively bring home a survival income level (Sharif 2000; Dessing 2002). It is probable that in this region the labor supply curve becomes more elastic than the labor demand curve (target income behavior leads to a unit elastic labor supply curve); therefore, as wages are bid down by cutthroat competition among desperate workers the DS imbalance only worsens and the market becomes dynamically unstable - as in a depression situation. Also deleterious, the nation’s human resources start to deteriorate as labor income no longer fully covers minimum social cost (Prasch 2005).

NE and the SL\&EM portray the labor market and employment relationship as a level playing field where DS sets efficient and fair wages and workers cannot be exploited because they can quite one job for another. IEIR claims, however, that they get to this conclusion only by unduly ignoring the governance structure that embeds the operation of DS in labor markets. The reality, according to IEIR, is that the governance structure - absent countervailing social reengineering -- is tilted in favor of employers and workers do not enter the DS arena with the same rights, endowments and market position as the employers. Employers are frequently corporations and thus a “collective capital” with ownership over large, valuable and long-lived assets and a workforce of perhaps hundreds or thousands; workers, on the other hand, bargain as individuals, cannot diversify their risks and dependency beyond one job (or, perhaps, two), typically have few fall-back assets, and have only one commodity to sell and are under 
considerable pressure to find a buyer (first, because each day’s labor has zero value if not sold; second, because the worker faces a minimum daily income requirement for family survival). Likewise, the entire structure of the law and property rights regime tilts bargaining power in favor of employers while in most years workers' bargaining power is further undercut because the labor market has an excess of unemployed job seekers relative to companies with job vacancies (Webb and Webb 1897; Craypo 1997; Kaufman 2003, 2007a).

The result, as pictured panel (a) of Figure 2, is that workers as a class are put in a disadvantaged and dependent position in wage determination, such as in an early capitalist laissez-faire labor market. Not surprisingly, therefore, the entire structure of wages, work conditions, and treatment of workers is lower than the NE theory is wont to portray. Particularly important is that the entire structure of compensating wage differentials is shifted down so that the wage penalty employers face for unsafe conditions, work intensification, and unfair treatment are smaller and therefore less protective. Also reducing employers’ incentive to adequately protect and conserve labor is that, unlike their buildings and capital equipment, employees are rented by the hour and thus firms lose less from labor spoilage than capital spoilage (Kaufman 2010b). The labor market is also less "free" than portrayed since the choice for many workers, given mobility constraints, boils down to "work at a low wage dissatisfying job at Company A or quit and get the same kind of job at Company B” (Appelbaum, Bernhardt, and Murnane 2003). Indeed, the imbalance between wages and profit, and lifestyles of employers and workers, may be so starkly different that one cannot help but conclude the latter are exploited. In the NE "level playing field" world, the economic surplus is typically portrayed as relatively evenly divided between profit income and wage income and, hence, the market outcomes look fair and square (i.e., the DS lines are drawn so they intersect somewhere in the middle of the 
diagram, such as Figure 1). In the IEIR world of structural inequality, however, a disproportionate share of the economy's surplus - absent redistributive taxes and transfers -goes to a relatively small group of people in the upper strata of the income and wealth distribution. Definitions of what constitutes exploitation differ (see Taylor 1979; Roemer 1982; Hahnel 2006), at a general level, however, IEIR contends that most people would agree with this proposition: some degree of income inequality between capital and labor is acceptable and legitimate (reflecting a differential reward to entrepreneurship, risk-taking, saving, etc.); as inequality increases at some point the distribution of income crosses over into "unfair" (or "unreasonable") and if allowed to increase even further it crosses over into exploitation. Consider, for example, if the DS curves intersect in panel (a) on the dashed line so labor gets only a reproduction level of income and capital gets the entire surplus. Since this is still a competitive outcome NE declares it free of exploitation; IEIR, however, declares it exploitative because the bulk of workers get only enough of their product to survive so they can return each day to the nation's factories, mills and stores to create and pass on to the upper class of property owners, employers and politically-connected consumers the rest of the GDP.

A central purpose of FL\&EM is to change endowments and rules of the game so the governance structure is more egalitarian, accessible, and democratic, thus yielding more balanced and reasonable terms and conditions of employment in the labor market and distribution of income in society. In terms of panel (a), the object of FL\&EM is to reengineer and rebalance the governance structure so the DS bands shift upward to the position of the pencilthin lines and yield a wage and conditions of employment that would have existed if the original playing field had not been so tipped. This illustrates Adam’s (1887) idea of "raising the plane of 
competitive action" and the institutional contention, illustrated in the earlier quote by Craypo (1997), that society and not economic law decides the labor outcomes yielded in labor markets. Raising the plane of competition can be achieved through a variety of means, many of which also correct market failures. Minimum wages and collective bargaining, for example, set a wage floor in the labor market closer to the pencil-thin DS lines (and offset monopsony power); unemployment insurance and old age pensions allow workers to have a higher reservation wage (and help cover labor's social overhead costs), and government training and manpower development programs give workers more valuable skills and greater bargaining power (and correct for the free market's undersupply of training due to companies' free riding behavior). Since all such labor programs redistribute power and income from employers and the affluent (who, as consumers, benefit most from low-priced goods), they inevitably arouse considerable political opposition from these groups. Part of the IEIR program for a "balanced capitalism," therefore, is to ensure that the parties with the most money (corporations, the affluent) are not allowed to buy the governance system that promotes their private interests; likewise, it is important that suffrage rights in the polity are widespread and equally protected. The presumption is that elected officials are more likely to put in place a balanced governance system, including employment laws and regulations and protection of collective bargaining rights, when they face a broader, more representative, and equally financed constituent base.

From a conservative point of view these types of labor laws and social welfare programs look like collectivist wealth redistribution, confiscation of private property, and unwise interference in competitive markets; from an IEIR perspective without them capitalism and democratic society are threatened by excessive extremes of wealth and privilege and the economic instability and social conflict they produce. Similarly, SL\&EM sees labor law as 
(mostly) an anti-competitive form of protectionism while FL\&EM sees the same "protectionism" as a social virtue that guards workers against oppressive and unfair terms and conditions of employment made possible by imperfect labor markets, a tipped institutional playing field, and an excess supply of job seekers.

Now transition attention to panel (e). Pictured are four alternative employment relation outcomes: win-win; win-lose; lose-win; and lose-lose. NE and SL\&EM assume the invisible hand guides employers and employees to adopt (approximately) efficient contracts where the joint surplus is maximized. Further, in a competitive market economy factor inputs receive a return proportional to their marginal value contribution to production; in the case of labor this means the wage rate paid workers is equal to the part of the output they help produce (the marginal product). Definitions of fairness differ and economists are reluctant to make judgments on this matter; nonetheless, many believe competitive outcomes pass the ethical test because labor receives it share of the fruits of production (called by Budd (2004) "marginal productivity justice”) and suffers no exploitation at the hands of employers. Since the size of the economic pie is as large as possible and distributed in what seems like an ethically satisfactory manner, one may judge that employers and employees are in the cell of panel (e) marked win-win. Here is another virtue of a competitive private-ordered economy and, presumably, another reason why trade unions and protective labor law are not needed in most situations.

From an IEIR perspective these conclusions are very inaccurate because they neglect the fundamentally human nature of labor. If labor was an inanimate commodity, it would have no consciousness of fairness and justice and, hence, no objection to alternative and perhaps quite unequal allocations. Labor is a unique factor input, however, because it is embodied in human beings (Edwards 2003; Kaufman 2010a). Accordingly, the structural inequality built into 
capitalism, and the resulting asymmetric outcomes, inevitably leads workers to regard the stateof-nature situation as unfair and unjust. This structural inequality is manifest at the market level in terms of the distributive process just reviewed. It is also manifest inside the workplace where employers and their hired managers (the "suits") have high salaries, secure jobs, interesting work, social status, and power to issue and enforce orders while the rank and file of employees (with blue and pink collars) experience the opposite on all these dimensions.

A common finding in laboratory experiments is that in an "ultimatum game" the party put into a highly unequal take it or leave it position refuses to accept the minimalist pay-off because it violates the standard of fairness (Miller 1991; Falk, Fehr and Fischbacher 2003). IEIR predicts the same for the employment relationship. That is, because of the large asymmetry in both market level and workplace outcomes workers come to view the deeper reality of the employment relationship not as win-win but win-lose. So viewed, workers naturally pull back on cooperation, commitment, and hard work; in panel (c), therefore, the same labor input of $\mathrm{L}_{1}$ yields less labor power. Employers, in turn, experience lower productivity and profit as labor power falls and come to see workers as uncooperative and lazy; they react, therefore, with a harsher attitude, tighter regime of workplace controls, and more punitive sanctions. This process creates a dynamic toward polarized positions where the two sides regard each other as adversaries embedded in a zero-sum game (Edwards 2003).

From an IEIR perspective, the nature of the capitalist employment relationship makes the base-line outcome in panel (e) the win-lose option. In all companies the ER features elements of both cooperation and conflict and to various degrees this translates into a win-lose (or lose-win) payoff; some companies, however, are able through forward-looking management, progressive HRM and an accommodative economic environment to restructure the ER into a win-win. The 
modern-day exemplar is variously known as the mutual gains enterprise, high involvement workplace, and high performance work system (HPWS) (Kochan and Osterman 1994; Applebaum, Berg, Kalleberg, and Bailey 2000). Empirical research finds that these transformed work systems have distinctly higher productivity and financial performance (Combs, Liu, Hall and Ketchen 2006), suggesting they outperform the win-lose or zero-sum type of ER. Yet research also finds that they represent a distinct minority of all workplaces (Blasi and Kruse 2006). This seems to suggest that for some reason in the labor markets of real life that competition is not moving employers to capture available gains from trade by creating HPWS systems.

The IEIR model points to a particular reason why HPWS firms are relatively rare. That is, their performance edge hinges on achieving a win-win ER but this outcome is unstable and difficult to maintain. The explanation goes back to panel (c) where shifts in the aggregate demand curve create boom and bust cycles. A mutual gain outcome requires that both capital and labor reap the benefits of cooperation, workers have secure jobs in return for loyalty and hard work, and employers live up to their promises - particularly when the going gets tough (Thompson 2003). However, employers are often forced (or say they are forced) by pressures of cost-cutting and short-term survival to renege on their commitments and institute actions, such as large lay-offs, wage and benefit cuts, and harsher discipline. These actions appear to workers to one-sidedly advance the interests of profit-making and shareholders over the interests of employees; they also seem to break the "we are partners” psychological contract (Edwards 2009). If these actions by employers seem particularly harsh, unequal, and opportunistic, workers may react through strikes, sabotage, union organizing, and street protests. Thus, win/win deteriorates to win/lose as a general case but may deteriorate further to lose/lose. 
IEIR depicts involuntary unemployment as a crucial feature and weakness of capitalism. It is a crucial feature because it gives employers a cheap but effective device to motivate and discipline labor (Edwards 1979; Bowles and Boyer 1988). A logically contradictory part of the NE model is the firm's perfectly elastic labor supply curve (not shown). The curve indicates that workers can at no cost quit one employer and immediately find another job at the same wage with a different company; the contradiction is that the workers have no incentive to provide more than a minimum of labor power and, hence competitive equilibrium is not efficient. The problem is that this part of the NE model ignores the wage-effort bargain in panel (d). One device to extract labor power is for the firm as part of its HRM strategy to pay a higher than market wage, as theorized in mainstream efficiency wage models (Shapiro and Stiglitz 1984; Akerlof 1990). Doing so increases labor power but if numerous firms do this it also raises the wage above the market-clearing level and creates a permanent reserve army of the unemployed. One may follow NE, cast this model in an optimization framework, and conclude that this kind of unemployment is not a "labor problem" because it creates the largest joint surplus (Boyer and Smith 2001); from an IEIR perspective, however, this is a labor problem because the structure of capitalism is dysfunctional in the sense it requires perhaps several million people to go without jobs so their plight motivates those who have jobs to work hard and obey the rules.

A principle of IEIR, as pointed out earlier, is that labor markets are divided into segments with partially attenuated mobility across them (Kerr 1977). A major purpose of antidiscrimination legislation has been to reduce these barriers and the structural inequality they give rise to. The most popular NE theory of discrimination claims, for example, that free market forces will automatically erode discriminatory employment practices arising from employers’ bigotry or prejudice (Becker 1957). This theory has difficulty, however, explaining why in the 
free market and mostly non-union era before the New Deal stark and pervasive discrimination existed in wages, occupations, promotion and training (Leonard 2003). Also difficult to explain purely on efficiency grounds is why professional schools in law, medicine and business into the 1970s so clearly discriminated in their admission policies on the basis of race, gender and religion (Epstein 1981). A popular NE theory attributes the small number of female doctors and lawyers in this era to the fact they voluntarily decided to not go to professional schools so they could better accommodate work and family (Polachek 1981). As in all matters discussed in this chapter, this NE theory has insight and explanatory power; the problem, however, is that it also neglects that part of the "voluntary choice" made by these women is based on opportunity costs, relative market prices, and preferences that are distorted by the tipped, discriminatory, and patriarchal nature of the governance structure within which DS are embedded (Albelda 1997; Gottfried 2006). From an NE perspective, civil rights and anti-discrimination laws are suspect because they interfere with demand, supply and free markets and, besides, free market forces eventually solve most of the problem; from an IEIR perspective, however, these laws are necessary so demand, supply and free markets are open to everyone and all workers are on a reasonably balanced playing field.

The labor market segmentation arising from discrimination is amplified by other forms of segmentation in the economy's institutional infrastructure. The efficiency wage idea discussed above, for example, explains the existence of a dual labor market economy with high wage firms and well developed ILMs in a primary labor market and low wage firms with highly externalized and insecure jobs in a secondary labor market (Bulow and Summers 1986). The factor that differentiates the two is the technology of production and the structure of the labor process. That is, if the technology entails jobs with considerable firm-specific skill, autonomy and effort 
discretion then firms create ILMs and use high wages to elicit effort; if the jobs are unskilled, easily learned and can be tightly controlled then the firms pay low wages and extract labor power through tight supervision, fast-paced assembly lines, and so on (Edwards 1979). Thus, discrimination causes differential access to the good jobs in the labor market and then the "rich get richer” over time as favored workers move up job/career ladders in ILMs and primary firms while disfavored workers stall-out in dead-end occupations or jobs with short advancement opportunities in secondary firms.

From an IEIR perspective, the most serious market defect and cause of labor problems in capitalist economies is widespread unemployment (Commons 1934; Kaufman 1997, 2003a). NE typically omits this consideration since it starts evaluation of labor law with the assumption that labor markets are in equilibrium (where the DS curves cross) and the only unemployment, therefore, is frictional and short-term in nature related to job search and geographic mobility (both good for the economy). In the half century before World War II, however, labor markets in all but a few years had millions of excess job seekers and a situation of $\mathrm{D}<\mathrm{S}$ (Lescohier 1919; Long 1958). The excess labor supply was not remedied by flexible wages nor was it caused by impediments such as minimum wage laws or unions (widespread only after the mid-1930s); rather, the economy suffered from a general situation of demand-deficient unemployment. In tandem with structural sources of inequality, pervasive excess supply of labor considerably worsened many of the labor problems of that era by undercutting workers' power to bargain for reasonable wages and conditions; short-circuiting the protective force of competition, and giving employers the upper-hand to manage employees in an autocratic and oppressive manner.

IX. IEIR: From the 1930s to Today 
We are now seven decades from the mass unemployment of the Great Depression era and the many labor problems it created that helped open the door to a growing body of labor and employment law. Conservative/neoliberal critics of IEIR say that in hindsight the New Deal was a huge mistake, labor and employment law has since then expanded to the point it makes American firms non-competitive in the global economy, and what America really needs to generate more jobs is a substantial roll-back of costly and inflexible labor law, collective bargaining and government entitlement (social safety net) programs. In closing this chapter, we need to briefly consider the merits of this argument.

IEIR, as indicated above, considers unemployment to be the most serious defect of capitalism and greatest cause of labor problems. From an IEIR perspective, therefore, the economist who probably made the greatest contribution in the $20^{\text {th }}$ century to improved employment relations was Englishman J.M. Keynes. Like IEIR economists, Keynes believed the "assume a competitive labor market" theory does not work in real life and, therefore, the Invisible hand of competition needs to be stabilized, regulated and balanced by the Visible Hand of government. Not coincidentally, Keynes advanced these then-heretical ideas in the middle point of the Great Depression, most notably in his famous book The General Theory of Employment, Interest and Money (1936).

IEIR and Keynesian macroeconomics have close intellectual ties, in part because Keynes’ wrote the General Theory with ideas from earlier works by Commons and other American institutional economists (Whalen 2008; Kates 2010). In other writings, Keynes also endorsed the New Deal labor program of the Roosevelt administration, including minimum wages, expanded collective bargaining, and social insurance programs such as unemployment insurance and social security (Moggridge 1982, Vol. 21: 438). The central message of both IEIR and Keynesian 
macroeconomics (KM) is that a laissez-faire economy is prone to serious boom and bust cycles and government needs to offset this instability by using fiscal and monetary policies in the macro-economy to keep aggregate demand at a steady full-employment level, supplemented with complementary stabilizing and redistributive programs in the labor market to maintain steady wage growth among working class and middle class households.

In the last three-four decades neoclassical economics and social philosophy of neoliberalism have grown considerably in appeal and the IEIR/KM viewpoint has correspondingly lost a significant share of academic and popular support. One sign of this retrogression is the sustained criticism neoclassical macro-economists have directed against the Keynesian model; another sign is the substantial displacement of IEIR in mainline labor economics by neoclassical-oriented theory (Boyer and Smith 2001; Kaufman 2010a). The attack on IEIR/KM originally and most influentially came from economists at Chicago, such as Friedman, Stigler, and Lucas, but now is taken up by a wide range of conservative-leaning economists.

A remarkable part of the neoclassical/neoliberal resurgence is their reinterpretation of the Great Depression, for many years taken as convincing evidence in favor of the IEIR/KM “imperfect capitalism” thesis. This reinterpretation began with Friedman at Chicago (Friedman and Schwartz 1963) but has recently found support among other notable economists, such as Nobel-laureate Edward Prescott (1999). They have collectively done what an earlier generation of economists would have thought impossible; that is, they have reversed the (apparent) lesson of the Great Depression with the claim that the length and severity of the debacle was not the fault of free market capitalism but was instead caused by labor law, unions, unwise government macroeconomic intervention, and government-supported market rigidities. Thus, from their point 
of view it is highly ironic for IEIR/KM to use the Great Depression as justification for "more government” when it was precisely government and allies (unions, etc.) that started the downturn and then transformed it into a decade-long depression.

Regarding labor markets and labor law, for example, Chari, Kehoe and McGrattan (2003) claim, “These poor [labor] policies turn what otherwise would be modest downturns into prolonged depressions” (p. 3); in a similar vein Ohanian (2009) concludes “the key to understanding the Depression is understanding and quantifying this labor market distortion” (p. 2314). These economists arrive at these conclusion using “assume a competitive labor market” reasoning. That is, involuntary unemployment means the price of labor is too high and therefore $\mathrm{D}<\mathrm{S}$; the evident solution to unemployment is to reduce wage rates until labor is cheap enough that employers hire all who want to work. The New Deal labor program, however, (allegedly) thwarted the labor market's self-correcting process by preventing wages from falling; in fact, it made the depression worse because minimum wages, social security, expanded collective bargaining and the other parts raised the price of labor and thus further reduced employment.

This argument has increasingly gained traction among economists is now influential and widely-cited (e.g., Parker 2007). But a closer examination reveals serious problems with it.

One has to appreciate in evaluating the free market argument that in the first half of the Great Depression both unions and labor law were a very small presence. The nation did not even have a federal child labor law when the depression started in 1929 (it came in 1938, along with a minimum wage) and, likewise, union density was about ten percent and nearly all of the mass production part of the economy was essentially union-free. It is true that after Franklin Roosevelt became president in early 1933 legislation (National Industrial Recovery Act) was enacted that encouraged an expansion of unions and minimum wages, but this can have nothing to do with 
the collapse of the economy into depression. Indeed, money wage rates were relatively flexible and declined by over one-quarter between 1929 and 1933; also of note, Roosevelt strongly resisted greater government deficit spending in his first term in office.

So, given this context, how were free labor markets operating in the early 1930s? Were they promoting efficiency and fairness and helping the economy get back to full employment? It helps to start the IEIR rebuttal with these two quotations from case studies of employment conditions during the 1930s. This type of case study evidence is an important way institutionalists try to confront theory with facts. The first come from a study of auto workers (Peterson 1987: 133):

"Foremen met workers' complaints about worsening working conditions with the perennial request to look out the window at the line of job seekers and the standard refrain of, 'if you cannot do the job, there is somebody in that line who can.' Many plants combined speed-up with a shift from piecework to day rates, keeping wages low as production increased at a rate that one study estimated from two to three times its predepression rate. Some workers were even forced to work overtime for no pay in order to keep their jobs.”

The second quotation comes from a study of San Francisco dockworkers (Nelson 1988:

106-07):

In San Francisco, the Embarcadero was known as the 'slave market,' but to many who witnessed it the shape-up bespoke of an even lower form of existence.... One longshoreman recalled that 'for thirty-five days, rain or shine, I was out there, on the waterfront from five in the morning till all the crews were filled, but I never got a job.' Of course, the shape-up system invited abuse, ranging from petty corruption to systematic extortion... where the men regularly kicked back 10 percent of their wages to the gang boss.”

Here from an IEIR perspective is the dark-side of a free labor market system that SL\&EM proponents tend to ignore or rationalize away. The IEIR perspective is quite different because employment outcomes such as described in these quotations are not treated as anomalies 
or the fault of government and unions, but, rather, a predictable outcome of laissez-faire capitalism.

In IEIR and KM theory, the one-quarter drop in money wages and one-third drop in prices from 1929 to 1933 unleashes a deflationary process of “destructive competition” or “race to the bottom” that is potentially quite destabilizing (Kaufman 1997; 2007b). The idea that competition can turn destructive and should therefore be restricted is antithetical to $\mathrm{NE}$ and SM\&LE theory; likewise, a fall in wages and prices according to competitive DS theory is desirable as a way to bring the economy back to a full employment equilibrium.

In IEIR theory, however, competition can turn destructive in a recession or depression for several reasons. Strong competition, for example, brings on wage cuts but wage cuts reduce aggregate demand in panel (c) of Figure 2 and drives the economy deeper into recession and unemployment. Also, wage cuts can become destabilizing because, as earlier described, labor supply expands when wage cuts reduce family income toward the survival level (the kinked labor supply curve idea). Competition can also be destructive when it reduces wage rates and family income below the social minima in panel (a) since workers’ physical and human capital begins to deteriorate. A situation of falling wages and prices also increases the real debt burden of firms and they react by cutting costs wherever possible. Since labor is typically the largest part of variable cost in the short-run, the brunt of cost reduction falls on workers in the form of layoffs, speed-ups, deteriorating working conditions, and harsher treatment. The labor market and competition provide them little protection, however, because compensating wage differentials are compressed or eliminated and many hungry jobseekers are available to employers. A final negative effect of strong competition in this situation is that the ratcheting down of wages and conditions of employment leads to feelings of unfairness, insecurity and bitterness among the 
employees, all of which undermine cooperative and high-productivity win-win employment relationships in panel (e).

Frances Perkins, Labor Secretary in the Roosevelt administration, summed-up the IEIR perspective when she said (quoted in Craypo 1997: 226):

"As a nation, we are recognizing that programs long thought of as merely labor welfare, such as shorter hours, higher wages, and a voice in terms and conditions of work, are really essential economic factors for recovery and for the technique of industrial management in a mass production age.”

This was the 1930s; what about today? FL\&EM and IEIR see great progress since the New Deal along the three major fronts of attack on labor problems: ameliorating labor market failures, balancing the institutional governance structure, and reducing unemployment. President Reagan famously asserted that the nine most feared words in the English language are "I'm from the government and I'm here to help you.” IEIR asks, however, that we look below the surface of appealing free market rhetoric and consider the record of what has been accomplished by government in labor markets. Consider, for example, a list of the major labor and employment laws enacted since World War II. A short list includes: Equal Pay Act, Civil Rights Act, Age Discrimination in Employment Act, Employee Retirement and Security Act, Occupational Safety and Health Act, Worker Adjustment and Retraining Act, Family Medical Leave Act, Americans with Disabilities Act, and the Patient Protection and Affordable Care Act.

The respective opinion on these laws of the American public and NE/SL\&EM economists is noticeably discordant. Hamermesh (2009) reports that the most researched labor policy issue in labor economics is the minimum wage. According to a 2006 national poll (reported at http://pew research.org/pubs/18/maximum-support-for-raising-the-minimum), 83 percent of Americans said they favored a $\$ 2.00$ increase in the minimum wage; economists 
Neumark and Washer, however, reflect a large body of economic opinion when they conclude in their new book Minimum Wages (2008), “we find it very difficult to see a good economic rationale for continuing to seek a higher minimum wage.” The belief of most IEIR economists is that the public has the correct position not only on the minimum wage but all of the other labor laws cited above. This does not mean these laws are perfect or cannot be improved; it does mean, however, that IEIR believes the public accurately perceives that these laws helped solve significant labor problems. Evidence in support of this belief is taken from the fact that political efforts in the USA to repeal old labor laws (e.g., the move to privatize social security in the Bush administration) and block several new laws (e.g., President Obama’s health care law) have failed.

Nonetheless, clearly the political tide in the last three decades has on balance favored giving a greater role to markets and paring back government regulation and collective bargaining. In this respect SL\&EM has clearly dominated FL\&EM. The decision of the state of Wisconsin in early 2011 to rescind collective bargaining rights for public sector employees is emblematic, as is the near-death experience of Obama's health care legislation. An IEIR interpretation is the following, with emphasis on two themes articulated in the quote from Commons (earlier featured) - the inevitability of contradictions in labor policy and the need to look at labor law as one part of a larger industrial relations system.

Here Keynes re-enters the story. After World War II the American government gradually started to practice Keynesian-inspired full-employment fiscal and monetary policies. The effect was dramatic - recessions were shallower and further apart, economic growth was fast-paced into the early 1970s, and the labor market stayed closer to full employment. If the economy is at or near full employment, then the NE "assume a competitive labor market” theory comes a step 
closer to reality and its implications for labor law and unions have more relevance. In particular, in a full employment economy workers do not need as much labor law protection, unions gradually transition from a protector of the underdog to a source of monopoly wages, and both laws and unions begin to appear to people as unnecessarily restrictive and cost-increasing. The apparent success of Keynesian full employment macroeconomic practices, therefore, undercut some of the need for the wage-raising and protective parts of the New Deal labor program. This was most true concerning protection and support of trade unions since new labor laws are mostly a one-time structural change in DS in labor markets but collective bargaining has a built-in dynamic push for "more” that in a full employment economy creates a growing problem of monopoly wages and benefits and cost-push inflation pressures (Mitchell 1980; Kaufman 2007c).

Union density in the private sector gradually declined over the years until in 2010 it was less than 8 percent (Hirsch and Macpherson 2011). This decline was partly an automatic economic response as higher-cost unionized firms gradually lost market and employment share to non-union competitors and foreign firms; partly it was also a product of an effort by the Reagan and Bush administrations to weaken unions through a variety of regulatory rulings, shifts in labor law enforcement, and budget reallocations (actions also applied to other areas of labor law, such as occupational safety and health). Here emerge contradictory forces, however.

On one hand, the decline of private sector unions, selective weakening of existing labor laws, growth of flexible work arrangements (e.g., contract and temporary employment), and process of globalization succeeded in creating a more competitive labor market since the early 1980s, exactly as NE and SL\&EM have advocated. The accompanying outcomes, however, were exactly what IEIR theory would predict - reemergence of an inequality of bargaining power for 
the middle-to-lower part of the workforce and growing structural inequality in the nation's governance structure and institutional rules governing the labor market. Inequality of bargaining power reemerged because workers lacked a viable union threat effect, American workers were now competing with low-wage workers in China, India and other countries, and lack of good jobs in America put workers into more of a "take it or leave it" situation. The governance structure also gradually tipped in favor of the interests of employers and the affluent due to growing political and financial clout by conservative and pro-business groups, declining clout by unions and other groups on the progressive/left side of the political spectrum, and a growing flood of money into political lobbying and elections.

These two structural shifts created a more competitive labor market, but "competitive” in this case is manifest not by removal of government restraints and movement to the DS equilibrium (Figure 1) but a shifting down of the DS curves (Figure 2 panel (a) from the pencilthin lines to the bands) and the entire plane of competition in the American labor market. Two important examples are decisions of the American government since 2000 to live with largescale illegal immigration and an undervalued Chinese currency, both of which in effect expand the supply of labor competing against American workers and increase profits relative to wages (if labor demand curves are inelastic, which evidence (Hamermesh (1993) suggests they are). Accordingly, real wages and family incomes stagnated for the middle and working classes, most of the productivity gains generated by the economy went to corporate profits and top-tier earners, and the income distribution gradually moved to greater inequality in favor of the rich (Economic Policy Institute 2011).

The rising income share for employers, property owners, and affluent creates buoyant financial markets, construction spending, and capital goods spending, all of which expand the 
supply side of the economy. The downside, however, is that a stagnant-to-modestly rising real wage and a falling income share for labor leads to anemic growth in household income, consumer spending, and aggregate demand - propped up for a time, perhaps, by a run-up in household debt. Eventually a structural shortfall of demand develops that price adjustments cannot solve, precipitating a sustained bout of overproduction (output $\mathrm{Q}_{1}$ in Figure 2 panel (c) but demand of $\mathrm{Q}_{2}$ ), large rise in unemployment, popping of real estate and financial market bubbles, and in a worst-case scenario descent into economic crisis.

These events, from an IEIR perspective, describe the economic crisis of 2007-2010. They are also eerily reminiscent of the economic crisis of the 1930s. As in the 1930s, more unions and redistributive labor laws are blunt and often costly measures to solve the problem of structural imbalance and economic inequality that afflicts the American labor market of the early 2010s. If these tools are not used, however, then society needs to come up with some other mechanism that preserves a reasonable balance in bargaining power and income distribution. What IEIR and FL\&EM are absolutely certain of is that a strategy of deregulation, deunionization, and wagecutting for solving American competitive problems will only worsen matters.

Free market theories of the "assume a competitive labor market" type are intellectual works of beauty and have insights not to be ignored; nonetheless, they are also a recipe for labor problems and economic mal-performance because they envision labor markets as operating no differently than commodity and financial markets. If the field of industrial relations has a central theme, it is that this doctrine is dangerously inaccurate in theory and harmful in practice.

\section{Conclusion}


From one point of view labor markets are highly competitive, employment practices are (mostly) efficient adaptations to underlying costs and constraints, and government solutions are typically inefficient and coercive. This point of view, most closely identified in the post-World War II period with the neoclassical economics and second L\&E tradition at the University of Chicago, leads to the conclusion that in most cases labor law and employment regulation should be kept to a minimum and used only when evidence of market failure is clear and compelling and other pro-market solutions are infeasible.

From another point of view -- most closely identified with the institutional economics/industrial relations and first L\&E tradition born in the early part of the twentieth century at the University of Wisconsin - external and internal labor markets are considerably imperfect and structurally unbalanced and, hence, wages, conditions and managerial employment practices tend to have significant elements of inefficiency, injustice and inhumanity. Further, from this point of view even if labor markets could be made highly competitive it is undesirable to do so since they are harmful to cooperative high productivity employment relations and the life interest of workers in jobs with reasonable security, stability and advancement opportunities. So viewed, capitalism and the work world can be materially improved by a complementary program of labor law, social insurance, availability of collective bargaining, and macroeconomic guidance that together deploy the visible hand of government to supplement, strengthen and in some cases restrain the invisible hand of self-interest and competition.

It is generally the case in employment disputes, as arbitrators, mediators and judges come to learn full-well, that neither side to an argument has a monopoly on facts and truth. Hence, the verdict has to be established by a careful and objective weighing of the evidence. In this chapter I have endeavored to present to the jury both the positive case for the IEIR/FL\&EM side of the 
labor law debate and a critical account (albeit hopefully fair and balanced) of the gaps and shortcomings in the NE/SL\&EM argument. Without question labor law, labor unions, and social safety net programs entail costs and sometimes cause economic inefficiency; the IEIR position, however, is that the "assume a competitive labor market" proposition that grounds the NE/SL\&EM evaluation of these institutions is biased because it accentuates their costs and minimizes their benefits. In effect, the "anti" side of the labor law debate asks the jury to evaluate labor law with a theoretical framework that inevitably leads to a base-line verdict of “guilty until proven innocent.” It does this by committing what Demsetz (1969) calls the “nirvana fallacy;” that is, evaluating imperfect human-made institutions against the outcomes of a (mostly) first-best set of markets and contracts. The essence of IEIR is to model labor markets and employment relationships in a more realistic and hence imperfect manner, with the effect of opening intellectual space for labor law and labor institutions to do good as well as harm. IEIR proponents have considerable faith, in turn, that if American social policy were to actually follow the deregulation regime explicit or implicit in SML\&E - for example, the list of recommendations/conclusions cited earlier from Posner's Law and Economics -- the nation would soon see a return of all the labor problems that FL\&EM worked so hard over the twentieth century to solve. 
References

Adams, Henry. 1887. “The Relation of the State to Industrial Action,” 1 Publications of the American Economic Association, pp. 7-85. [reprinted in Joseph Dorfman, ed., 1969, Two Essays: The Relation of the State to Industrial Action and Economics \& Jurisprudence, Boston: Kelley]. . 1897. Economics and Jurisprudence, New York: Macmillan.

Addison, John, and Barry Hirsch. 1997. “The Economic Effects of Employment Regulation: What Are the Limits?” In Bruce Kaufman, ed., Government Regulation of the Employment Relationship. Ithaca: Cornell University Press, pp. 125-78.

Akerlof, George. 1990. “The Fair Wage-Effort Hypothesis and Unemployment,” 105 Quarterly Journal of Economics 255-84.

Albelda, Randy. 1997. Economics and Feminism: Disturbances in the Field, New York: Twayne.

Amsden, Alice, and Ajit Singh. 1994. “The Optimal Degree of Competition and Dynamic Efficiency in Japan and Korea.” 38 European Economic Review, pp. 941-51.

Appelbaum, Eileen, Peter berg, Arnie Kalleberg, and Thomas Bailey. 2000. Manufacturing Advantage: Why High-Performance Systems Pay Off, Ithaca: Cornell University Press. , Annette Bernhardt, and Richard Murnane. 2003. Low Wage America: How Employers are Reshaping Opportunity in the Workplace, New York: Russell Sage.

Arthurs, Harry. 2006. Fairness at Work: Federal Labor Standards for the $21^{\text {st }}$ Century. Ottawa: HRSDC. 
Arthurs, Harry. 2007. “Compared to What? Reflections on the Future of Comparative Labor Law,” Comparative Labor Law \& Policy Journal, 28: 591-612.

Atkinson, Glen, and Theodore Oleson. 1998. "Commons and Keynes: Their Assault on Laissez-Faire,” 32 Journal of Economic Issues, pp. 1019-30.

Baldamus, Wilhelm. 1961. Efficiency and Effort. London: Tavistock.

Becker, Gary. 1957. The Economics of Discrimination. Chicago: University of Chicago Press. . 1976. The Economic Approach to Human Behavior. Chicago: University of Chicago Press. . 1993. "Nobel Lecture: The Economic Way of Looking at Behavior," 101 Journal of Political Economy, 385-409.

Befort, Stephen, and John Budd. 2009. Invisible Hands, Invisible Objects: Bringing Workplace Law and Public Policy into Focus, Stanford: Stanford Economics and Finance.

Bewley, Truman. 1999. Why Wages Don't Fall in a Recession. Cambridge, MA: Harvard University Press.

Biddle, Jeff. 1996. “H. Gregg Lewis,” in Warren Samuels, ed., American Economists of the Late $20^{\text {th }}$ Century, Brookfield, Edward Elgar, pp. 174-93.

Blasie, Joe, and Douglas Kruse. 2006. “U.S. High Performance Work Practices at Century’s End,” 45 Industrial Relations, pp. 457-78.

Blaug, Mark. 1985. Economic Theory in Retrospect, $4^{\text {th }}$ ed., new York: Cambridge University Press. . 2007. "The Fundamental Welfare Theorems of Modern Welfare Economics, Historically Contemplated.” 39 History of Political Economy 185-207. 
Block, Richard, Karen Roberts, and R. Oliver Clark. 2003. Labor Standards in the United States and Canada. Kalamazoo: Upjohn.

Boeri, Tito, and Jan van Ours. 2008. The Economics of Imperfect Labor Markets. Princeton: Princeton University Press.

Boulding, Kenneth. 1957. “A New Look at Institutionalism,” 47 American Economic Review, pp.1-12.

Bowles, Samuel, and Robert Boyer. 1988. "Labor Discipline and Aggregate Demand: A Macroeconomic Model,” 78 American Economic Review, pp. 395-400.

Boyer, G. and Smith, R. 2001. "The Neoclassical Tradition in Labor Economics," Industrial and Labor Relations Review, Vol. 54, No. 2, pp. 199-223.

Bronfenbrenner, Martin. 1956. "Potential Monopsony in Labor Markets," 9 Industrial and Labor Relations Review, pp. 577-88.

Budd, John. 2004. Employment with a Human Face: Balancing Efficiency, Equity, and Voice. Ithaca, NY: Cornell University Press.

Bulow, Jeremy, and Lawrence. Summers. 1986. “A Theory of Dual Labor Markets with Application to Industrial Policy, Discrimination, and Keynesian Unemployment.’ 4 Journal of Labor Economics, pp. 376-414.

Cahuc, Pierre, and Ándre Zylberberg. 2004. Labor Economics, Cambridge: MIT Press.

Card, David, and Alan Krueger. 1995. Myth and Measurement: The New Economics of the Minimum Wage. Princeton: Princeton University Press.

Chandler, Alfred Jr. 1977. The Visible Hand: The Managerial Revolution in American Business. Cambridge: Harvard University Press. 
Chari V., Patrick Kehoe, and Ellen McGrattan. 2003. “Accounting for the Great Depression,” 27 Federal Reserve Bank of Minneapolis Quarterly Review, pp. 2-8.

Coase, Ronald. 1937. “The Nature of the Firm,” 4 Economica 386-405. . 1992. 82 “The Institutional Structure of Production.” American Economic Review, pp. 713-19.

Combs, J., Liu, Y., Hall, A.., and D. Ketchen. 2006. “How Much Do High-Performance Work Practices Matter? A Meta-Analysis of Their Effects on Organizational Performance,” 59 Personnel Psychology, pp. 501-28.

Commons, John. 1919. Industrial Goodwill, New York, McGraw-Hill. . 1934. Institutional Economics: Its Place in Political Economy, New York, Macmillan. . 1950. The Economics of Collective Action, Madison: University of Wisconsin Press. , and John Andrews. 1916. Principles of Labor Legislation, New York: Harper.

Cooter, Robert, and Thomas Ulen. 2010. Law \& Economics, $6^{\text {th }}$ ed., new York: Pearson. Craypo, Charles. 1997. "Alternative Perspectives on the Purpose and Effects of Labor Standards Legislation,” in Bruce Kaufman, ed., Government Regulation of the Employment Relationship, Madison: Industrial Relations Research Association, pp. 221-52.

Davis, John. 1992. The Economic Surplus in Advanced Economies, Brookfield: Elgar.

Deakin, Simon, and Frank Wilkinson. 2005. Law of the Labor Market: Industrialization, Employment, and Legal Evolution, New York: Oxford University Press.

Demsetz, Harold. 1969. “Information and Efficiency: Another Viewpoint,” 12 Journal of Law and Economics 1-22.

Derber, Milton. 1970. The American Idea of Industrial Democracy, Urbana-Champaign: University of Illinois Press. 
Dessing, Markye. 2002. "Labor Supply, the Family and Poverty: the S-Shaped Labor Supply Curve,” 49 Journal of Economic Behavior and Organization, pp. 433-58.

Dorfman, Joseph. 1969. “Henry Carter Adams: Harmonizer of Liberty and Reform,” in Joseph Dorfman, ed., Two Essays by Henry Carter Adams, New York: Kelly, pp. 3-55.

Doucouliagos, Hristos, and Thomas Stanley. "Publication Selection Bias in Minimum Wage Research? A Meta-regression Analysis,” 47 British Journal of Industrial Relations, pp. 406-28.

Doeringer, Peter, and Michael Piore. 1971. Internal Labor Markets and Manpower Analysis. Lexington, MA: Lexington Books.

Dow, Gregory. 1997. "The New Institutional Economics and Employment Regulation,” in Bruce. Kaufman, ed., Government Regulation of the Employment Relationship, Madison, Industrial Relations Research Association, pp. 57-90.

Dunlop, John. 1957. “The Task of Contemporary Wage Theory,” in George Taylor and Frank Pierson, eds., New Concepts in Wage Determination, New York: McGraw-Hill, pp. 117 $-39$.

. 1958. Industrial Relations Systems, New York: Holt. . 1984. "Industrial Relations and Economics: The Common Frontier of Wage Determination.” In Proceedings of the Thirty-Seventh Annual Meeting, Madison: Industrial Relations Research Association, pp. 9-23. . 1994. “Organizations and Human Resources: Internal and External Markets.” In Clark Kerr and Paul Staudohar, eds., Labor Economics and Industrial Relations: Markets and Institutions. Cambridge, MA: Harvard University Press, pp. 375-400. 
Economic Policy Institute. 2011. The State of Working America, Washington: Economic Policy Institute.

Edwards, Paul. 2003. “The Employment Relationship and the Field of Industrial Relations,” in Paul Edwards, ed., Industrial Relations: Theory and Practice, $2^{\text {nd }}$ ed., London: Blackwell, pp. 1-36. . 2009. 'The Employment Perspective in Strategic HRM.' In John Storey, Patrick Wright, and David Ulrich, eds., The Routledge Companion to Strategic Human Resource Management, London: Routledge, pp. 40-51.

Edwards, R. (1979). Contested Terrain: The Transformation of Work in Twentieth Century America. New York: Basic Books.

Ekelund, Robert, and Robert Hebert. 2007. A History of Economic Thought and Method, $5^{\text {th }}$ ed., Long Grove: Waveland.

Ely, Richard. 1884. The Past and Present of Political Economy. Baltimore: Johns Hopkins University Press.

Emmett, Ross. 1999. Selected Essays by Frank H. Knight, Vol. 2. Chicago: University of Chicago Press.

Epstein, Cynthia. 1981. Women in Law. New York: Basic Books.

Epstein, Richard. 1983. “A Common Law for Labor Relations: A Critique of the New Deal Labor Legislation,” 92 Yale Law Journal, pp. . 1984. "In Defense of the Contract at Will," 51 University of Chicago Law Review, pp.

Erickson, Christopher, and Daniel Mitchell. 2008. "Monopsony as a Metaphor for the Emerging 
Post-Union Labor Market,” 146 International Labor Review, pp. 163-87.

Estlund, Cynthia. 2006. “The Death of Labor Law?” Annual Review of Law and Social Science, 2: 105-23.

Estlund, Cynthia. 2010. Regoverning the Workplace: From Self-regulation to Co-regulation. New Haven: Yale University Press.

Falk, Armin, Ernst Fehr, and Urs Fischbacher. 2003. “On the Nature of Fair Behavior,” 41 Economic Inquiry, pp. 20-26.

Fehr, E. and Falk, A. 1999. "Wage Rigidity in a Competitive Incomplete Contract Market,” 107 Journal of Political Economy 106-34. , and ___ 2006. "Fairness Perceptions and Reservations Wages - The Behavioral Effects of Minimum Wage Laws,” 121 Quarterly Journal of Economics, pp. 1347-81.

Fishback, Price. 1998.”Operations of ‘Unfettered’ Labor Markets: Exit and Voice in American Labor Markets at the Turn of the Century,” 36 Journal of Economic Literature, pp. 72265.

Fleischer, Belton, and Thomas Kniesner. 1980. Labor Economics: Theory, Evidence and Policy, $2^{\text {nd }}$ ed. Engle Wood Cliffs, NJ: Prentice-Hall.

Freedman, Craig. 2008. Chicago Fundamentalism: Ideology and Methodology in Economics. Hackensack, NJ: World Scientific.

Freeman, Richard, and James Medoff. 1984. What Do Unions Do? New York: Basic Books. Fried, Barbara. 1998. The Progressive Assault on Laissez-Faire: Robert Hale and the First Law and Economics Movement. Cambridge: Harvard University Press. 
Friedman, Milton. 1953. “The Methodology of Positive Economics.” In Milton Friedman, ed., Essays in Positive Economics, pp. 3-43, Chicago: University of Chicago Press. , and Rose Friedman. 1990. Free to Choose. New York: Harcourt Brace. , and Anna Schwartz. 1963. A Monetary History of the United States, 1867-1960. Princeton: Princeton University Press.

Furubotn, Erik, and Rudolf Richter. 2005. Institutions \& Economic Theory, $2^{\text {nd }}$ ed. Ann Arbor: University of Michigan Press.

Galbraith, John. 1967. The New Industrial State. Boston: Houghton-Mifflin.

Gottfreid, Heidi. 2006. "Feminist Theories of Work.” In Marek Korczynski, Randy Hodson, and Paul Edwards, eds., Social theory at Work, Oxford: Oxford University Press, pp. 121-54.

Groenewegem John, Antoon Spithoven, and Annette Van Den Berg. 2010. Institutional Economics: An Introduction. New York: Palgrave Macmillan.

Gross, James, and Lance Gompa. 2009. Human Rights in Labor and Employment Relations, Champaign-Urbana, Labor and Employment Relations Association.

Hahnel, Robin. 2006. “Exploitation: A Modern Approach.” 38 Review of Radical Political Economics, pp. 175-92.

Hamermesh, Daniel. 1993. Labor Demand. Princeton: Princeton University Press. 2009.

Hirsch, Barry, and David Macpherson. 2011. Union Coverage and Data Book, Washington: BNA.

Hovenkamp, Herbert. 1990. "The First Great Law and Economics Movement," 42 Stanford Law Review 993-1058. 
Huang, Peter. 2009. “Emotional Reactions to Law and Economics: Market Metaphors, and Rationality Rhetoric,” in Mark White, ed., Theoretical Foundations of Law and Economics, New York: Cambridge University Press, pp. 163-83.

Isaac, Joe. 2007. “Reforming Australian Industrial Relations,” Journal of Industrial Relations, 49 (3): 411-35.

Jacoby, Sanford. 2005. “Economic Ideas and the Labor Market: Origins of the Anglo-American Model and Prospects for Global Diffusion,” Comparative Labor Law \& Policy Journal, 26: $43-78$.

Johnson, George. 1975. "Economic Analysis of Trade Unionism,” 65 American Economic Review 23-38.

Jolls, Christine. (2006). "Law and the Labor Market,” 2 Annual Review of Law and Social Science, pp. 359-85. , Cass Sunstein, and Richard Thaler. 1998. “A Behavioral Approach to Law and Economics,” 50 Stanford University Law Review, pp. 1471-1550.

Just, Richard, Hueth, Darrell, and Andrew Schmitz. 2004. The Welfare Economics of Public Policy. Northampton, MA: Edward Elgar.

Kates, Steven. 1998. Say’s Law and the Keynesian Revolution, Northampton: Elgar. . 2010. “Influencing Keynes: The Intellectual Origins of the General Theory,” 18 History of Economic Ideas, pp. 33-64.

Kaufman, Bruce. 1988. How Labor Markets Work: Reflections on Theory and Practice by John Dunlop, Clark Kerr, Richard Lester and Lloyd Reynolds. Lexington, MA: Lexington Books. 
. 1997. "Labor Markets and Employment Regulation: The View of the 'Old'

Institutionalists." In Bruce Kaufman, ed., Government Regulation of the Employment Relationship. Madison: IRRA, pp. 11-56.

. 1999. "Expanding the Behavioral Foundations of Labor Economics,” 52 Industrial and

Labor Relations Review, pp. 361-91.

. 2002. "Reflections on Six Decades in Industrial Relations: An Interview with John

Dunlop,” 55 Industrial and Labor Relations Review 324-48.

. 2003a. "John R. Commons and the Wisconsin School on Industrial Relations

Strategy and Policy,” 56 Industrial and Labor Relations Review 3-30.

. 2003b. "The Organization of Economic Activity: Insights from the Institutional

Theory of John R. Commons," 52 Journal of Economic Behavior and Organization, 71-96.

. 2004. The Global Evolution of Industrial Relations: Events, Ideas, and the IIRA.

Geneva: International Labor Organization.

. 2005. “The Social Welfare Objectives and Ethical Principles of Industrial Relations.” In

John Budd. and James Scoville, eds., The Ethics of Human Resources and Industrial

Relations, Champaign, Labor and Employment Relations Association, pp. 23-59.

. 2006. "Labor Institutionalism and Industrial Relations: A Century of Boom and Bust,"

47 Labor History 295-318.

. 2007a. "The Institutional Economics of John R. Commons: Complement and

Substitute for Neoclassical Economic Theory, 5 Socio-Economic Review 3-46.

. 2007b. "Historical Insights: The Early Institutionalists on Trade Unionism and Labor

Policy.” In James Bennett and Bruce Kaufman, eds., What Do Unions Do: A Twenty- 
Year Perspective, New Brunswick, NJ: Transaction Press, pp. 46-78. . 2007c. What Do Unions Do? Evaluation and Commentary.” In J. Bennett and B. Kaufman, eds., What Do Unions Do: A Twenty-Year Perspective. New Brunswick, NJ: Transaction Press, pp. 520-62. 2008. Managing the Human Factor: The Early Years of Human Resource Management in American Industry, Ithaca: Cornell University Press. . 2009. "Labor Law and Employment Regulation: Neoclassical and Institutional Perspectives.” In K. Dau-Schmidt, S. Harris, and O. Lobel, eds., Labor and Employment Law and Economics. Northampton, MA: Edward Elgar, pp. 3-58. . 2010a. "Chicago and the Development of Twentieth Century Labor Economics.” In Ross Emmett, ed., The Elgar Companion to the Chicago School of Economics. Northampton, MA: Edward Elgar, 128-51. . 2010b. “The Theoretical Foundation of Industrial Relations and Implications for Labor Economics and Human Resource Management,” 64 Industrial and Labor Relations Review, pp. 74-108. . 2010c. "Institutional Economics and the Minimum Wage: Broadening the Theoretical and Policy Debate,” 63 Industrial and Labor Relations Review, pp. 427-53.

Kerr, Clark. 1977. Labor Markets and Wage Determination. Berkeley: University of California Press. , and Abraham Siegel. 1955. "The Structuring of the Labor Force in Industrial Society: New Dimensions and New Questions,” 8 Industrial and Labor Relations Review, pp. 151-68. Keynes, John. 1936. The General Theory of Employment, Interest, and Money, London: Macmillan. 
Kochan, Thomas. 2005. Restoring the American Dream: A Working Families’'Agenda. Cambridge: MIT Press. . and Paul Osterman. 1994. The Mutual Gains Enterprise, Cambridge: Harvard Business School Press.

Koot, Gerald. 1987. English Historical Economics, 1870-1926. Cambridge: Cambridge University Press.

Lazear, Edward. 2000. “Economic Imperialism,” 115 Quarterly Journal of Economics 99-145.

Leonard, Jonathon. 2003. “Advancing Equal Employment Opportunity, Diversity, and Employee Rights: Good Will, Good Management, and Legal Compulsion, in Bruce Kaufman, Richard Beaumont and Roy Helfgott, eds., Industrial Relations to Human Resources and Beyond: The Evolving Process of Employee Relations Management, Armonk: M.E. Sharpe, pp. 258-92.

Lescohier, Don. 1919. The Labor Market. New York: Macmillan.

Lester, Richard. 1941. The Economics of Labor. New York: Macmillan. . 1952. “A Range Theory of Wage Differentials,” 5 Industrial and Labor Relations Review, pp. 433-50.

Levendis, John. 2007. “The Fallacy of Wage Cuts and Keynes’ Involuntary Unemployment,” 29 Journal of the History of Economic Thought, pp. 309-29.

Lipsey, Richard, and Kevin Lancaster. 1956. "The General Theory of the Second Best,” 24 The Review of Economic Studies, pp. 11-32.

Long, Clarence. 1958. The Labor Force under Changing Income and Employment, Princeton: Princeton University Press.

Manning, Alan. 2003. Monopsony in Motion, Princeton: Princeton University Press. 
Marsden, David. 1999. A Theory of Employment Systems, London, Oxford University Press.

Mas-Colell, Andreu, Whinston, Michael, and Jerry Green. 1995. Microeconomic Theory. New York: Oxford University Press.

McCloskey, Deirdre. 1997. "The Good Old Coase Theorem and the Good Old Chicago School: A Comment on Zerbe and Medema.” In Coasean Economics: Law and Economics and the New Institutional Economics, ed. Steven Medema, pp. 239-48. Boston: Kluwer.

McIntyre, Richard, and Yngve Ramstad. 2002. “John R. Commons and the Problem of International Labor Rights,” 36 Journal of Economic Issues, pp. 293-302.

McNulty, Paul. 1980. The Origins and Development of Labor Economics. Cambridge: MIT Press.

Mercuro, Nicholas, and Steven Medema. 1997. Economics and the Law: From Posner to PostModernism, Princeton: Princeton University Press.

Medema, Steven. 2010. “Chicago Law and Economics.” In Ross Emmett, ed., The Elgar Companion to the Chicago School of Economics. Northampton, MA: Edward Elgar, $160-74$.

Miller, Gary. 1991. Managerial Dilemmas, Cambridge, Cambridge University Press.

Mitchell, Daniel. 1980. Unions, Wages, and Inflation. Washington: Brookings.

Moggridge, Donald. 1982. The Collected Writings of John Maynard Keynes, Vol. 21. London: Macmillan.

Moss, David. 1996. Socializing Security: Progressive-Era Economists and the Origins of American Social Policy, Cambridge: Harvard University Press.

National Labor Relations Board. 1985. Legislative Hearings on the National Labor Relations 
Act. Vols. 1 and 2. Washington, DC: Government Printing Office.

Nelson, Bruce. 1988. Workers on the Waterfront: Seamen, Longshoremen, and Unionism in the 1930s, Champaign-Urbana: University of Illinois Press.

Neumark, David, and W. Wascher. 2008. Minimum Wages. Cambridge: MIT Press.

Ohanian, Lee. 2009. “What—or Who - Started the Great Depression?” 144 Journal of Economic Theory, pp. 2310-35.

Osterman, Paul. 1987. “Choice of Employment Systems in Internal Labor Markets,” 26 Industrial Relations, pp. 46-67. . Thomas Kochan, Richard Locke, and Michael Piore. 2001. Working in America: A Blueprint for a New Labor Market, Cambridge: MIT Press.

Overtfeldt, Johan van. 2007. The Chicago School: How the University of Chicago Assembled the Thinkers That Revolutionized Economics and Business. Chicago: Agate.

Parker, Randall. 2007. The Economics of the Great Depression. Northampton, MA: Edward Elgar.

Pearson, Heath. 1997. Origins and Law and Economics: The Economists’ New Science of Law 1830-1930. Cambridge: Cambridge University Press.

Peterson, Joyce. 1987. American Automobile Workers, 1900-1933. Albany: State University of New York Press.

Plott, Charles. 2010. “Overview: Highlights of the Benefits of Basic Science in Economics,” in John Siegfried, ed., Better Living Through Economics, Cambridge: Harvard University press, pp. 6-35.

Polachek, Solomon. 1981. “Occupational Self-Selection: A Human Capital Approach to Sex 
Differences in Occupational Structure,” 63 Review of Economics and Statistics, pp. 6069.

Posner, Richard. 1984. “Some Economics of Labor Law,” 51 University of Chicago Law Review, pp 988-1011. 2007. Economic Analysis of Law, $7^{\text {th }}$ ed., Austin, Wolters-Kluwer.

Prasch, Robert. 2005. “The Social Cost of Labor,” 39 Journal of Economic Issues, pp. 1-7.

Prescott, Edward. 1999. "Some Observations on the Great Depression,” 23 Federal Reserve Bank of Minneapolis Quarterly Review, pp. 25-29.

Rader, B. 1966. The Academic Mind and Reform: The Influence of Richard T. Ely in American Life, Lexington: University of Kentucky Press.

Reynolds, Lloyd. 1954. Labor Economics and Labor Relations, $2^{\text {nd }}$ ed. Englewood Cliffs, NJ: Prentice-Hall.

Reder, M. 1982. “Chicago Economics: Permanence and Change,” 20 Journal of Economic Literature 1-38.

Rizvi, S. Abu Turab. 2007. “Postwar Neoclassical Microeconomics.” In W. Samuels, J. Biddle and J. Davis, eds., A Companion to the History of Economic Thought. London: Blackwell, pp. 377-94.

Rodrik, Dani. 2007. “Why Economists Disagree,” Web Blog at http://rodrik.typepad.com/dani_rodriks_weblog/economists_blindspots/.

Roemer, John. 1982. A General Theory of Exploitation and Class, Cambridge: Harvard University Press.

Rubbery, Jill, and Damian Grimshaw 1998. "Integrating the Internal and External Labor Markets,” 22 Cambridge Journal of Economics, pp. 199-220. 
Rutherford, M. 2001. "Institutionalism Then and Now,” 15 Journal of Economic Perspectives 173-94.

Samuels, Warren, and A. Allan Schmid. 1981. Law and Economics: An Institutional Perspective. Boston: Kluwer-Nijhoff. , and Steven Medema, and A. Allan Schmid. 1997. The Economy as a Process of Valuation, Lyme: Edward Elgar.

Schmid, A. Allan. 2004. Conflict and Cooperation: Behavioral and Institutional Economics, Malden: Blackwell.

Schwab, Stewart. 1997. “The Law and Economics Approach to Workplace Regulation,” in Bruce Kaufman, ed., Government Regulation of the Employment Relationship, Madison, Industrial Relations Research Association, pp. 91-124.

Segal, Martin. 1986. "Post-Institutionalism in Labor Economics: The Forties and Fifties Revisited,"39 Industrial and Labor Relations Review 388-403.

Sen, Amartya. 1999. Commodities and Capabilities. New York: Oxford University Press. Shapiro, Carl, and Joseph Stiglitz. 1984. "Equilibrium Unemployment as a Worker Discipline Device,” 74 American Economic Review, pp. 433-44.

Sharif, Mohammed. 2000. "Inverted 'S' - The Complete Neoclassical Labor Supply Function,” 139 International Labor Review, pp. 379-408.

Shulman, Beth. 2003. The Betrayal of Work: How Low-Wage Jobs Fail Thirty Million Americans and Their Families, New York, New Press.

Shultz, George, and John Coleman. 1961. Labor Problems: Cases and Readings, $2^{\text {nd }}$ ed. New York: McGraw Hill. 
Simon, Herbert. 1951. “A Formal Theory of the Employment Relationship,” 19 Econometrica, pp. 293-305.

Slichter, Sumner. 1931. Modern Economic Society, $2^{\text {nd }}$ ed., New York: Holt.

Solow, Robert. 1990. The Labor Market as a Social Institution, New York, Blackwell.

Stigler, George. 1966. The Theory of Price, $3^{\text {rd }}$ ed., New York: Macmillan. . 1982. The Economist as Preacher and Other Essays. Chicago: University of Chicago Press.

Sunstein, Cass. 2004. The Second Bill of Rights, New York: Basic Books.

Taylor, James. 1977. “Exploitation Through Contrived Dependence,” 11 Journal of Economic Issues, pp. 51-59.

Thompson, Paul, 2003. “Disconnected Capitalism: Or Why Employers Can’t Keep Their Side of the Bargain,” 17 Work, Employment and Society, pp. 359-78. , and Christy Newsome. 2004. "Labor Process Theory, Work, and the Employment Relationship,” in Bruce Kaufman, ed., Theoretical Perspectives on Work and the Employment Relationship, Champaign-Urbana, Labor and Employment Relations Association, pp. 133-62,

Thurow, Lester. 1983. Dangerous Currents: The State of Economics. New York: Random House.

Varian, Hal. 2010. Intermediate Microeconomics: A Modern Approach, $8^{\text {th }}$ ed. New York: Norton.

Wachter, Michael. 2004. “Theories of the Employment Relationship: Choosing Between Norms and Contracts,” in Bruce Kaufman, ed., Theoretical Perspectives on Work and the Employment Relationship, Champaign-Urbana: Labor and Employment Relations 
Association, pp. 163-94.

, and Randall Wright. 1990. “The Economics of Internal Labor Markets,” 29 Industrial Relations, pp. 240-62.

Watkins, Gordon. 1922. An Introduction to the Study of Labor Problems, New York: Thomas Crowell.

Webb, Sidney, and Beatrice Webb. 1897. Industrial Democracy, London: Longmans, Green.

Whalen, Charles. 2008. “John R, Commons and John Maynard Keynes on Economic History and Policy: The 1920s and Today,” Journal of Economic Issues, Vol. 42, No. 1, pp. 225-42.

Williamson, Oliver. 1985. The Economic Institutions of Capitalism. New York: Free Press. 
Figure 1: Competitive Labor Market

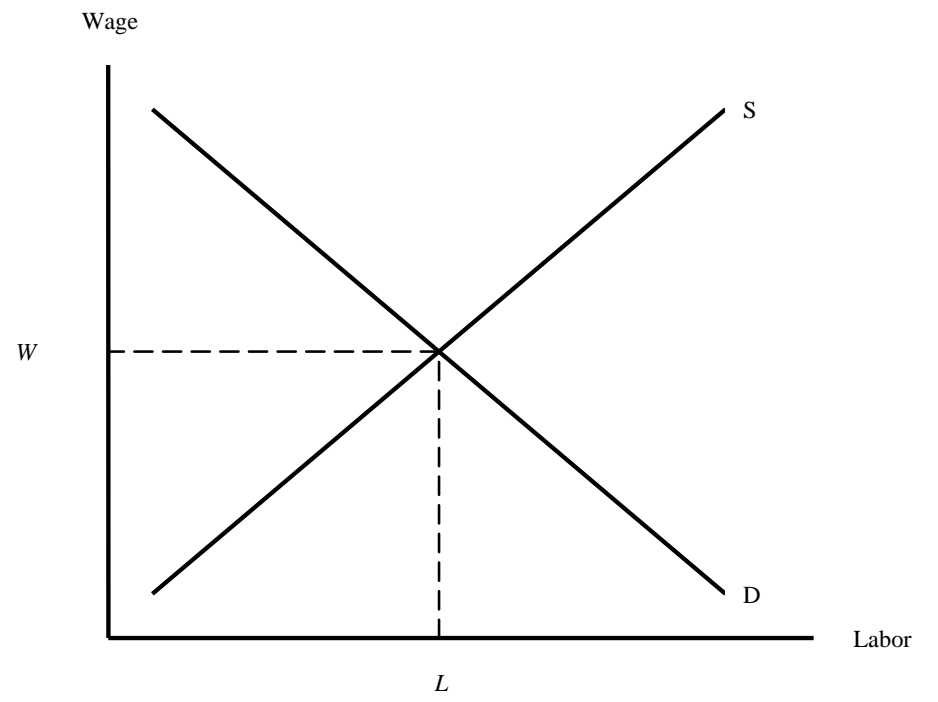




\section{Figure 2: IEIR Model of Labor Markets}

\section{And Employment Relationship}

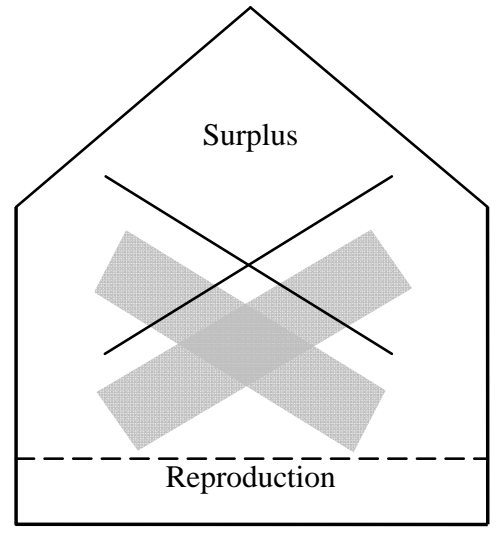

(a) Economy and Labor Market

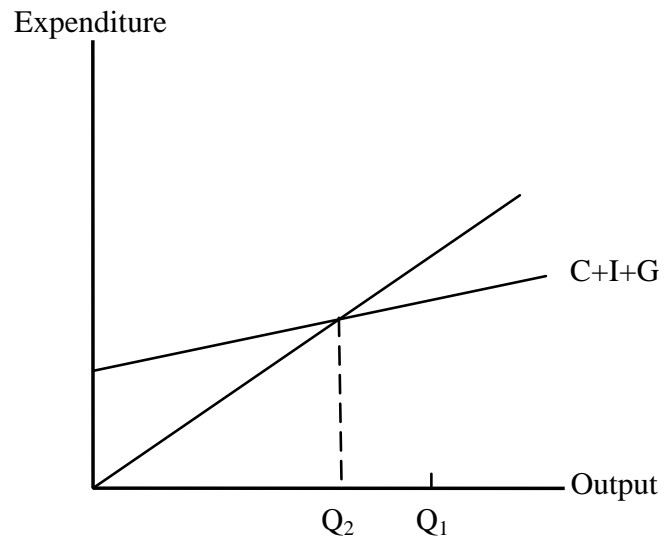

(c) Aggregate Demand/Supply

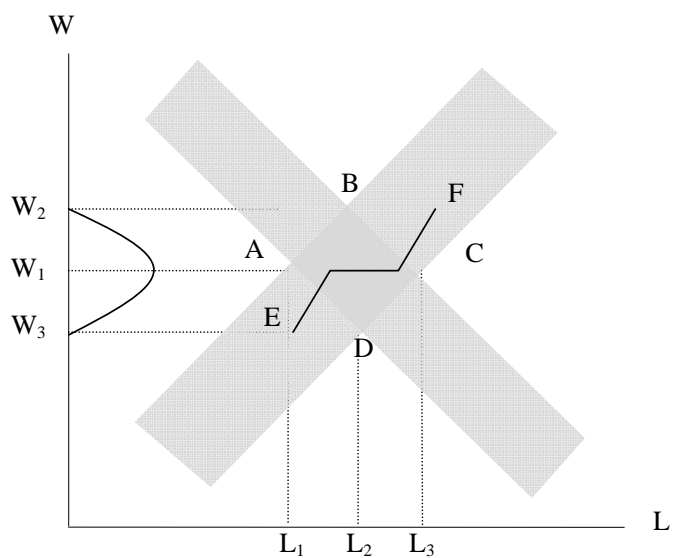

(b) The Area of Indeterminacy

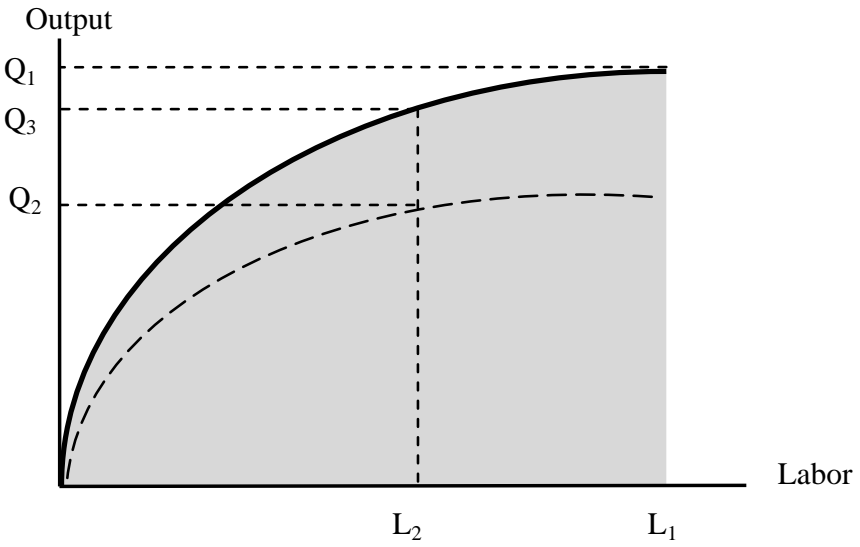

(d) Labor Process

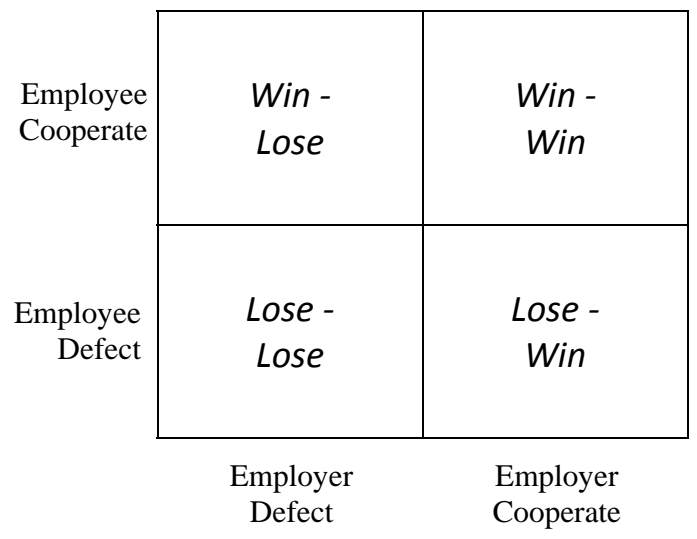

(e) Employment Relationship 